\title{
Imidazo[1,2-b]pyrazole-7-Carboxamide Derivative Induces Differentiation-Coupled Apoptosis of Immature Myeloid Cells Such as Acute Myeloid Leukemia and Myeloid-Derived Suppressor Cells
}

\author{
Edit Kotogány ${ }^{1,2}$, József Á. Balog ${ }^{1,2}$, Lajos I. Nagy ${ }^{3}$, Róbert Alföldi ${ }^{2,4}$, Valeria Bertagnolo ${ }^{5}$, \\ Federica Brugnoli ${ }^{5}$, András Demjén ${ }^{3}$, Anita K. Kovács ${ }^{3}$, Péter Batár ${ }^{6}$, Gabriella Mezei ${ }^{6}$, \\ Renáta Szabó ${ }^{7}$, Iván Kanizsai ${ }^{3}{ }^{10}$, Csaba Varga ${ }^{7}$, László G. Puskás ${ }^{1,3}$ and \\ Gábor J. Szebeni 1,3,7,*(D) \\ 1 Laboratory of Functional Genomics, Institute of Genetics, Biological Research Centre, Temesvári krt. 62, \\ H6726 Szeged, Hungary; kotogany.edit@brc.hu (E.K.); balog.jozsef@brc.hu (J.Á.B.); \\ laszlo@avidinbiotech.com (L.G.P.) \\ 2 PhD School in Biology, University of Szeged, H6726 Szeged, Hungary; r.alfoldi@astridbio.com \\ 3 Avidin Ltd., Alsó kikötő sor 11/D, H6726 Szeged, Hungary; 1.nagy@avidinbiotech.com (L.I.N.); \\ a.demjen@avidinbiotech.com (A.D.); a.kovacs@avidinbiotech.com (A.K.K.); \\ i.kanizsai@avidinbiotech.com (I.K.) \\ 4 AstridBio Technologies Ltd., Wimmer Fülöp u. 1, H6728 Szeged, Hungary \\ 5 Department of Morphology, Surgery and Experimental Medicine, University of Ferrara, Via Fossato di \\ Mortara 70, 44121 Ferrara, Italy; valeria.bertagnolo@unife.it (V.B.); bgf@unife.it (F.B.) \\ 6 Department of Hematology, Faculty of Medicine, University of Debrecen, Nagyerdei körút 98, \\ H4032 Debrecen, Hungary; pbatar@med.unideb.hu (P.B.); gmezei@med.unideb.hu (G.M.) \\ 7 Department of Physiology, Anatomy and Neuroscience, Faculty of Science and Informatics, \\ University of Szeged, Közép fasor 52, H6726 Szeged, Hungary; szaborenata88@gmail.com (R.S.); \\ vacs@bio.u-szeged.hu (C.V.) \\ * Correspondence: szebeni.gabor@brc.hu
}

Received: 28 May 2020; Accepted: 17 July 2020; Published: 20 July 2020

\begin{abstract}
Chemotherapy-induced differentiation of immature myeloid progenitors, such as acute myeloid leukemia (AML) cells or myeloid-derived suppressor cells (MDSCs), has remained a challenge for the clinicians. Testing our imidazo[1,2-b]pyrazole-7-carboxamide derivative on HL-60 cells, we obtained ERK phosphorylation as an early survival response to treatment followed by the increase of the percentage of the Bcl-xl ${ }^{\text {bright }}$ and pAkt ${ }^{\text {bright }}$ cells. Following the induction of Vav1 and the AP-1 complex, a driver of cellular differentiation, FOS, JUN, JUNB, and JUND were elevated on a concentration and time-dependent manner. As a proof of granulocytic differentiation, the cells remained non-adherent, the expression of CD33 decreased; the granularity, CD11b expression, and MPO activity of HL-60 cells increased upon treatment. Finally, viability of HL-60 cells was hampered shown by the depolarization of mitochondria, activation of caspase-3, cleavage of Z-DEVD-aLUC, appearance of the sub-G1 population, and the leakage of the lactate-dehydrogenase into the supernatant. We confirmed the differentiating effect of our drug candidate on human patient-derived AML cells shown by the increase of CD11b and decrease of CD33+, CD7+, CD206+, and $\mathrm{CD} 38^{\text {bright }}$ cells followed apoptosis $\left(\mathrm{IC}_{50}: 80 \mathrm{nM}\right)$ after treatment ex vivo. Our compound reduced both CD11b+/Ly6C+ and CD11b+/Ly6G+ splenic MDSCs from the murine $4 \mathrm{~T} 1$ breast cancer model ex vivo.
\end{abstract}

Keywords: acute myeloid leukemia; myeloid-derived suppressor cells; differentiation; apoptosis 


\section{Introduction}

Myeloproliferative neoplasms (MPNs) and myelodysplastic syndromes (MDS) are diseases of the hematopoietic stem cells in the bone marrow (BM) where an excess of immature cells is produced, which can frequently evolve to different myeloid leukemias [1,2]. The group of myeloid cells have been determined by the WHO classification, including granulocytic (neutrophil, eosinophil, and basophil), monocytic/macrophage, erythroid, megakaryocytic, and mast cell lineages [1]. The acute myelogenous/myeloid leukemia (AML) is the most common acute leukemia in adults with the incidence of 4.3 in the USA per 100,000 person-years. The AML has the shortest survival among leukemias (in 5 year survival $=24 \%$ ), especially in the elderly (at age $\geq 65$ years) the AML predicts the worst overall median survival (2.67 months) [3]. The AMLs represent a group of heterogeneous forms of myeloid malignancies with diverse genetic abnormalities and different stages of myeloid differentiation. The AMLs originate from myeloid stem cells or myeloid blasts halted in an immature state during hematopoiesis where more than $20 \%$ of blasts can be detected in the BM which counteracts with the production of normal blood cells [4].

Current treatment of these myeloid malignancies (MPNs, MDS, and AML) is different. There is no available curative treatment for any type of MPNs. The aims of therapies in MPNs are to limit the severity of symptoms to avoid thrombohemorrhagic complications, and limit anemia and splenomegaly $[5,6]$. The aims of the therapies in the case of MDS are also to diminish the symptoms, improve the quality of life and decrease progression to AML. Allogeneic stem cell transplantation can be considered under the age of 45 in high risk patients. Supporting cares are blood transfusion and the administration of erythropoietin. Chemotherapy for MDS is performed by the administration of 5-azacytidin, decitabine, and lenalidomide [7]. The treatment of AML mostly relies on high dose chemotherapy. Hematopoietic stem cell transplantation is recommended for younger patients with high risk, therapy refractory or relapsed disease with available HLA-matched donors. The aim of the first line treatment, called induction phase therapy, is to eradicate the leukemic clone and achieve complete remission. The second phase is called consolidation therapy, which helps maintaining complete remission by eliminating minimal residual disease. During induction therapy cytarabine and anthracycline are given, except subtype M3. The overall survival of AML remained poor, however novel therapies have been approved by the FDA, which are CPX-351 (daunorubicin/cytarabine), enasidenib (IDH2 inhibitor), midostaurin (FLT3 inhibitor), and gemtuzumab ozogamicin antibody-drug conjugate (GO) targeting CD33+ cells [8]. The acute promyelocytic leukemia (APL; the AML subtype M3) is treated mainly by all-trans retinoic acid (ATRA) and arsenic trioxide $[9,10]$. The prototype model used in our study was the human cell line, HL-60 promyeloblasts isolated form a female leukemia patient in 1977 presumed as acute promyelocytic leukemia (APL), but later reclassified to acute myeloblastic leukemia FAB-M2 because of the absence of $t(15: 17)$ translocation [11-13]. The lineage-uncommitted HL-60 cell line is suitable to model patient-derived samples responsive to differentiation induced chemotherapy. It has been shown that treatment of immature HL-60 cells by ATRA or DMSO resulted in granulocytic differentiation [14,15]. The phorbol ester 12-O-tetradecanoylphorbol 13-acetate (TPA), or 1,25-dihydroxyvitamin D3, induced the differentiation of HL-60 cells into a macrophage like adherent phenotype [16,17]. However, ATRA failed the clinical management of AML lacking the PML-RAR $\alpha$ target fusion protein frequent in APL $[18,19]$.

Chemotherapy-induced differentiation has been addressed in the late 1970s and still remained a therapeutic challenge to treat immature myeloid leukemias with high need for novel effective compounds [19]. We have previously synthetized a 67 member imidazo[1,2-b]pyrazole-7-carboxamide compound library with potent cytotoxic effect on HL-60 cells [20], and optimization of structure-activity relationship (SAR) resulted in the design of seven more active compounds [21]. These agents induced apoptosis in nanomolar range on HL-60 cells, but the way of action was not revealed. In order to explore the mechanism of action, our imidazo[1,2-b]pyrazole-7-carboxamide derivative, published earlier as DU325 [21], was further investigated to elicit its cytotoxic effect on human HL-60 and primary patient-derived AML cells. 
Another pathologic condition of myeloid expansion is the "emergency" granulo-monocytopoiesis in most of the solid malignancies in which, an army of immature myeloid cells leave the bone marrow, called monocytic and granulocytic myeloid-derived suppressor cells (MDSCs) [22]. We have previously reviewed this myeloid infiltrate in solid tumors, how is orchestrated by MDSCs [23]. The murine MDSCs are $\mathrm{CD}_{11} \mathrm{~b}^{+}$and $\mathrm{Gr}^{+}$heterogeneous populations of immature myeloid cells developed from bone marrow common myeloid progenitors [24], MDSCs are precursors of granulocytes, monocytes, macrophages, and dendritic cells. MDSCs are classified as $\mathrm{Ly}_{6 \mathrm{C}^{+}}$monocytic (M-MDSC) and $\mathrm{Ly}_{6 \mathrm{G}}{ }^{+}$granulocytic (G-MDSC) subpopulations in mice [25]. Due to the lack of Gr1 homologue in humans, the identification of MDSCs is not so evident, human MDSCs consist of phenotypically more heterogeneous population of myeloid cell precursors, briefly M-MDSC $\left(\mathrm{CD} 11 \mathrm{~b}^{+}, \mathrm{HLA}^{-\mathrm{DR}}{ }^{-/ \mathrm{low}}, \mathrm{CD}^{+} 3^{+}\right.$,

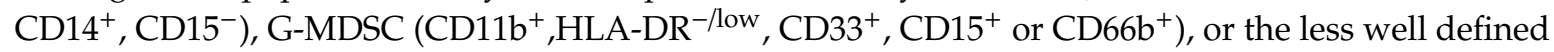
more immature MDSCs $\left(\mathrm{CD} 14^{-}, \mathrm{CD} 15^{-}\right)$[26,27]. In contrast to AML, MDSCs are not malignant cells, but promote tumor growth by several mechanisms including their inherent immunosuppressive activity, promotion of neoangiogenesis, mediation of epithelial-mesenchymal transition and altering cancer cell metabolism. These protumoral functions of MDSCs offer a myriad of potential anticancer therapeutic targets that we have previously reviewed [28]. We have recently reported the immunomodulatory effect of cisplatin via the suppression of splenic MDSCs in the 4T1 murine breast cancer model [29].

Because MDSCs are immature myeloid cells with immunosuppressive capacity, differentiation into mature myeloid cells, thereby restoration of antitumor T-cell immunity has been proven a promising therapeutic strategy [30,31]. Three agents-the calcitriol receptor agonist 1,25-dihydroxyvitamin D3 (vitamin D3) [32,33], the retinoic acid receptor agonist ATRA [34], and TLR7/8 agonist resiquimod [35]—-have been verified to mature MDSCs and reduce tumor nursing condition of immunosuppression [28].

Based on these findings we addressed to investigate the cytotoxic and differentiating effect of our imidazo[1,2-b]pyrazole-7-carboxamide derivative on splenic immature myeloid cells, both on $\mathrm{M}$ - and G-MDSCs accumulated in $4 \mathrm{~T} 1$ breast cancer-bearing mice.

\section{Results}

\subsection{DU325 Drives Survival Pathways as an Early Response to Treatment in HL-60 Cells}

In order to study the underlying mechanism of action of our recently developed drug candidate, DU325 with anti-leukemic effect [21], the prototype model of human acute myeloblastic leukemia, the HL-60 cells, were treated and assayed. HL-60 cells have been widely used earlier to test differentiation induced chemotherapy [36-38]. We have previously observed the asynchronous response of HL-60 cells in terms of morphology treated with DU325 and decided to obtain single cell protein expression data in a subpopulation of cells (bright) by using flow cytometry. We investigated ERK1/2 (extracellular-signal regulated kinases, alternatively MAPK mitogen-activated protein kinases) phosphorylation at Thr202/Tyr204 because ERK has been reported to be involved in myeloid differentiation of HL-60 cells $[36,39,40]$. The short-term treatment $(2 \mathrm{~h})$ of HL-60 cells with $1 \mu \mathrm{M}$ and 5 $\mu \mathrm{M}$ DU325 induced $13 \pm 1.89 \%(p<0.001)$ and $20 \pm 1.49 \%(p<0.001)$ of $\mathrm{pERK}^{\text {bright }}$ positive cells, respectively (Figure 1A and Figure S1A). The accumulation of Bcl-xl has been reported to suppress apoptosis during monocytic differentiation process of HL-60 cells via ERK dependent fashion [41,42]. Indeed, we could detect the increase of the percentage of Bcl-xl ${ }^{\text {bright }}$ cells with a peak at $50.3 \pm 5.5 \%$ $(p<0.001$ ) upon $1 \mu \mathrm{M}$ DU325 treatment (Figure 1B and Figure S1B). Another factor, the Akt (also known as Protein kinase B or RAC-alpha serine/threonine-protein kinase) that has been reported regulating survival during the differentiation of myeloid cells via NF-kB-dependent induction of Bcl-xl [43]. The percentage of cells with high pAkt (Ser473) was detected $20 \pm 4 \%(p<0.001)$ after incubation with 200 nM DU325 (Figure 1C and Figure S1C). The higher concentrations of DU325 caused a decline in the percentage of $\mathrm{Bcl}$-xl ${ }^{\text {bright }}$ and $\mathrm{pAkt}{ }^{\text {bright }}$ cells probably because of the previously reported apoptotic effect [21]. 
A

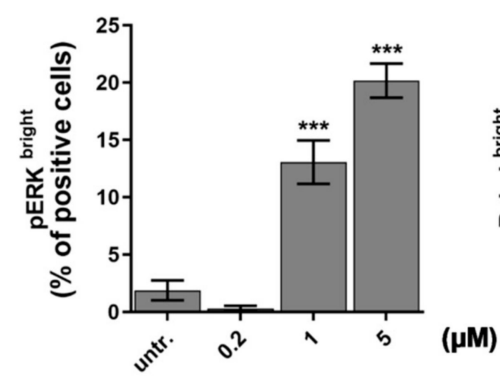

B

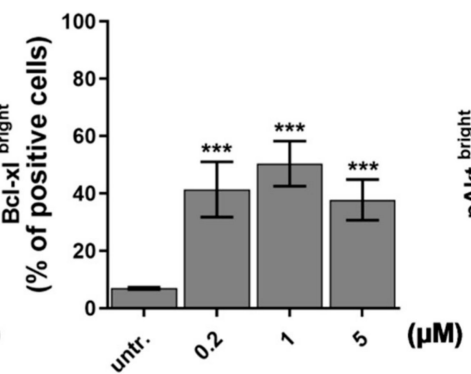

C

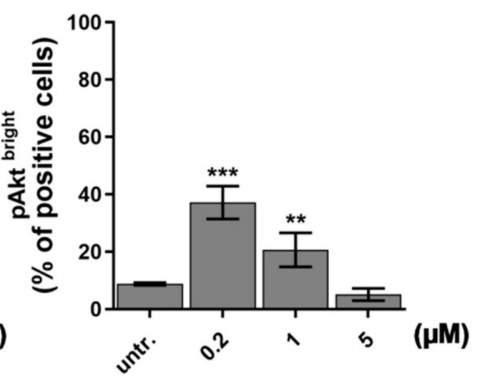

Figure 1. Drug candidate DU325 drives survival pathways as an early response to treatment in HL-60 cells. Using flow cytometry, we obtained ERK phosphorylation (pERK1/2, Thr202/Tyr204) (A) as an early response to DU325 stimulation followed by the increase of the percentage of the Bcl-xl (B) and pAkt (Ser473) bright cells (C). Cells were treated as described in the Materials and Methods Section 4.12 .4 for $2 \mathrm{~h}$ to assess ERK1/2 phosphorylation, and for $24 \mathrm{~h}$ to assess the upregulation of the anti-apoptotic Bcl-xl ${ }^{\text {bright }}$ and pAkt ${ }^{\text {bright }}$ cells. Data are shown as arithmetic mean values \pm standard deviation from triplicate experiments. Statistical significance was calculated in relation to untreated cells and set to ${ }^{* *} p<0.01,{ }^{* *} p<0.001$.

\subsection{DU325 Induces Differentiation of HL-60 Cells}

One of the master regulators of myeloid differentiation is Vav1, the hematopoietic cell-specific form of Vav proteins. Vav1 could act via several mechanisms, such as its guanine exchange factor (GEF) activity of GDP/GTP [44], regulating cell motility via cytoskeletal reorganization or modulation of gene expression [45]. The GEF activity of Vav1 is dependent on phosphorylation by either Syk, Zap70, Src, or JNK kinases [37], but Vav1 can have a direct effect on the transcriptional machinery as a component of the transcriptionally active complex or interacting with transcription factors, ribonucleoprotein complexes independent of its GEF activity [46-48]. We could detect the accumulation of Vav1 in whole cell lysates (Figure 2A and Figure S2A) and in the nuclei (Figure 2B and Figure S2B) of HL-60 cells with $50 \%$ increase treated with $200 \mathrm{nM}$ or $1 \mu \mathrm{M}$ DU325, respectively, as early as $24 \mathrm{~h}$. Additionally, the increase of the phosphorylation of Vav1 on Tyr-174 residues was detected in the whole cell lysates (Figure 2C) and in the nuclei (Figure 2D). 
A
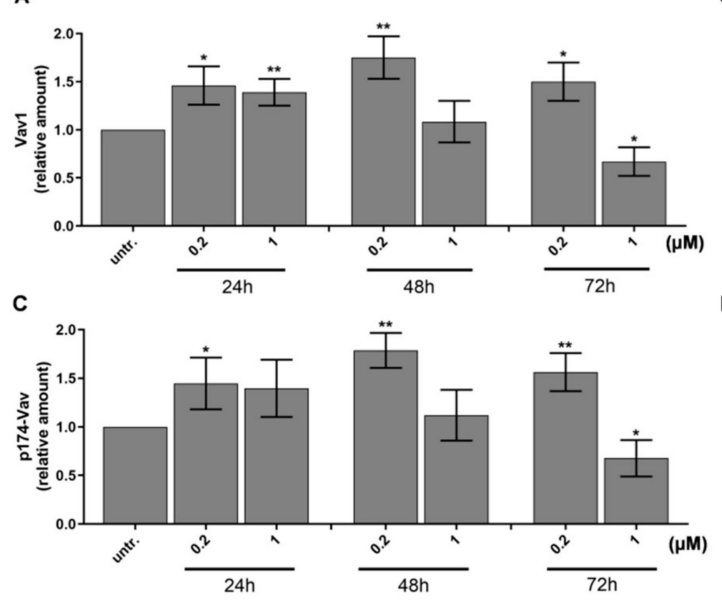
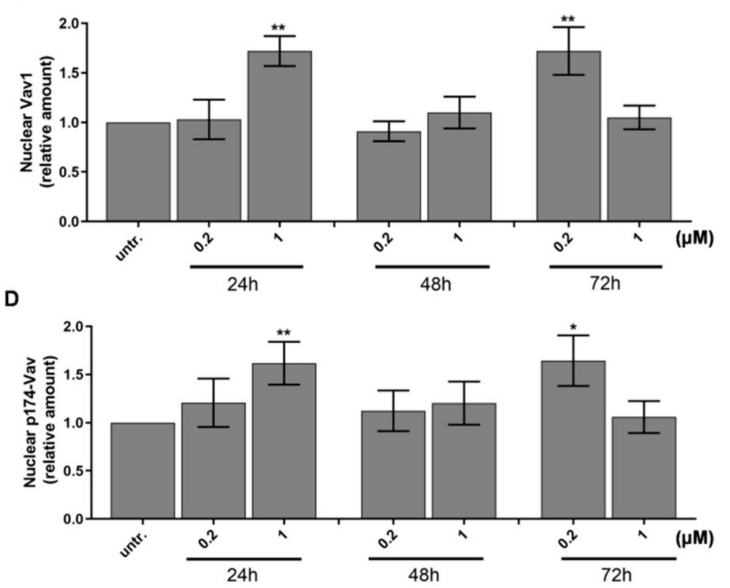

Figure 2. DU325 affects both cellular and nuclear levels of Vav1 in HL-60 cells. Relative levels of Vav1 in whole cells (A) and in the nuclei (B), and p174-Vav1 (Tyr174) in whole cells (C) and in the nuclei (D) from HL-60 cells grown in the presence of DU325 at the reported concentrations for the indicated times (h). Cells were assayed as described in the Materials and Methods Section 4.10. The values are deduced from the densitometry of immunochemical bands normalized with $\beta$-Tubulin for whole cells or with Lamin B for the nuclei as internal controls of loaded proteins (Figure S2). Data are shown as arithmetic mean values \pm standard deviation from triplicate experiments. Statistical significance was calculated in relation to untreated cells and set to ${ }^{*} p<0.05,{ }^{* *} p<0.01$.

Mollinedo et al. published that differentiation of HL-60 cells upon stimulation with 1 alpha,25-dihydroxyvitamin D3 required the expression of transcription factor activator protein 1 (AP-1) family members, multiple protein complexes such as FOS and JUN, JUNB, or JUND [49]. The FOS can heterodimerize with JUN members, while the JUN proteins can either homo- or heterodimerize to bind to the target sequences of transcriptionally active DNA elements [50]. We investigated the expression of the AP-1 subunits because both ERK1/2 [51,52] and Vav1 can play a role in the activation of the AP-1 pathway [53,54]. We observed a gradual increase in the expression of FOS (4-times, $p<0.001$ ) (Figure 3A), JUN (4-times, $p<0.01$ ) (Figure 3B), and JUND ( $2.5 \times$ times, $p<0.01)$ (Figure 3D) after $6 \mathrm{~h}$ treatment with $200 \mathrm{nM}$ DU325, while JUNB elevated by $40 \mathrm{nM}$ DU325 after $12 \mathrm{~h}(1.8 \times$ times, $p<0.01$ ) (Figure 3C). 
A
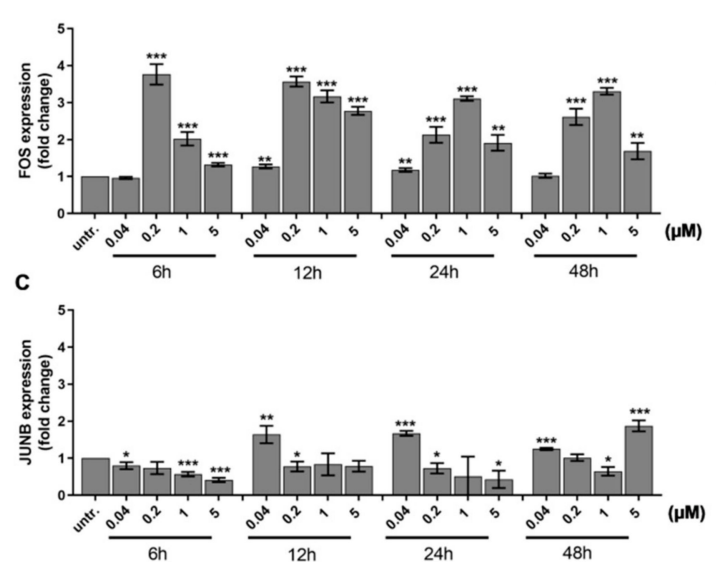

B
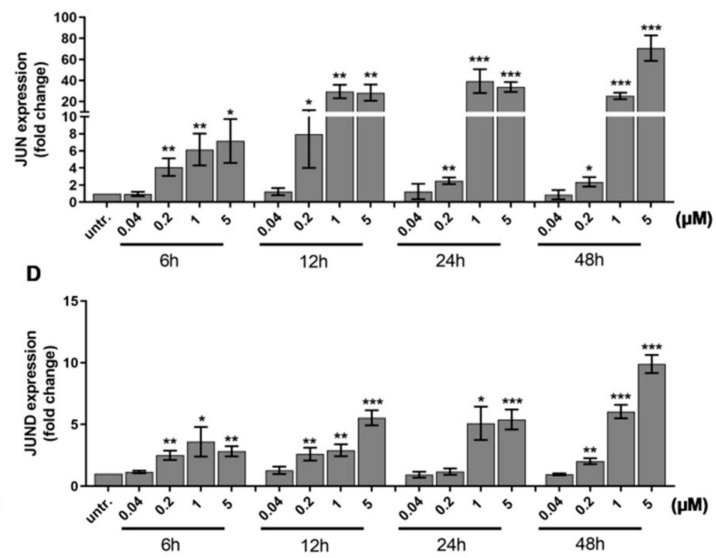

Figure 3. The expression of the members of the AP-1 TF (TF = transcription factor) complex, a driver of cellular differentiation, FOS (A), JUN (B), JUNB (C), and JUND (D), was elevated in a concentration and time dependent manner detected by qRT-PCR. Cells were assayed as described in the Materials and Methods Section 4.9. Data are shown as arithmetic mean values \pm standard deviation from triplicate experiments. Statistical significance was calculated in relation to untreated cells and set to $p<0.05$, ** $p<0.01,{ }^{* * *} p<0.001$.

The differentiation of HL-60 immature acute myeloid leukemia cells has been reported with decrease in the expression of early hematopoietic progenitor marker CD33 (Sialic Acid-Binding Ig-Like Lectin 3) and an increase of matured myeloid marker CD11b $[55,56]$. Next, we investigated the expression of these markers and showed a concentration and time dependent decrease of CD33 as early as $6 \mathrm{~h}$ after to $40 \mathrm{nM}$ DU325 treatment with 2-fold decrease $(p<0.001)$ detected by qRT-PCR (Figure $4 \mathrm{~A}$ ). The percentage of $\mathrm{CD} 11 \mathrm{~b}$ cells was followed by flow cytometry in order to monitor the size and granularity of the cells at single cell resolution. The induction of $\mathrm{CD} 11 \mathrm{~b}$ positive cells proportional to the maturation of HL-60 started from 5\% (24 h to $40 \mathrm{nM}$ DU325, $p<0.01)$ and reached a plateau at $90 \%(72 \mathrm{~h}$ $200 \mathrm{nM}$ DU325, $p<0.001$ ) (Figure 4B and Figure S3). Next, we followed the fate of HL-60 cells, whether the differentiation leads to granulocytic or monocytic direction. The FSC-SSC (FSC = Forward scatter, SSC $=$ Side scatter) dot plots showing increasing granularity supported the granulocytic differentiation (Figure S3). In order to clarify the result of maturation MPO (myeloperoxidase) activity, a marker of neutrophil granulocytes was measured after $48 \mathrm{~h}$ treatment with DU325. The differentiating agent DU325 at $200 \mathrm{nM}$ resulted in the elevation of MPO activity $4757 \pm 205$ vs. (versus) untreated $3335 \pm$ $363 \mathrm{U} / \mathrm{mg}$ protein $(p<0.01)$ with a maximum of $6405 \pm 901 \mathrm{U} / \mathrm{mg}$ protein $(5 \mu \mathrm{M})(p<0.01)$ (Figure $4 \mathrm{C})$. 
A

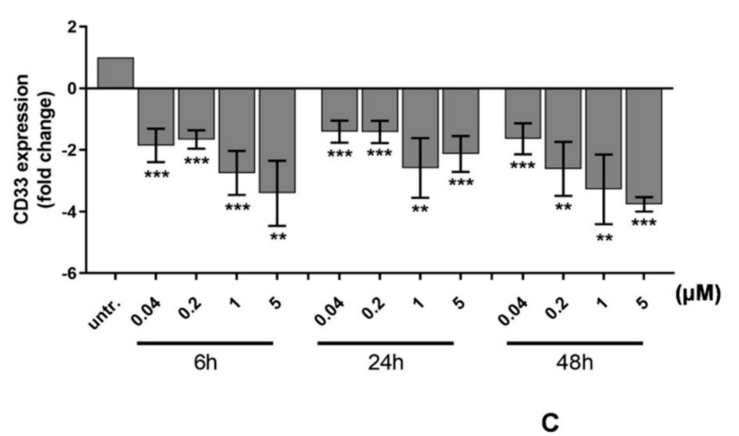

B

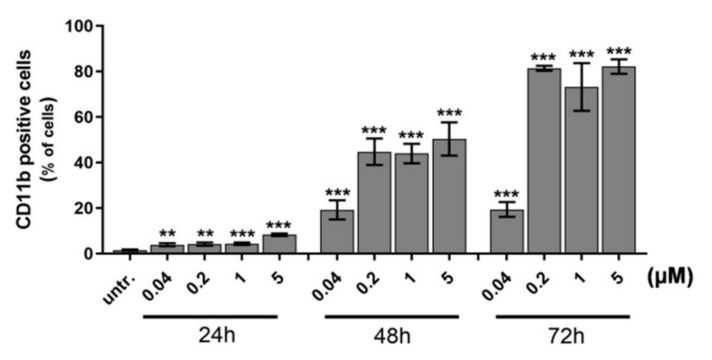

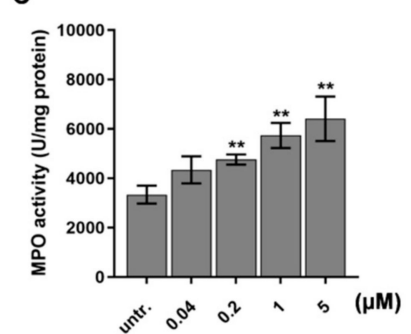

Figure 4. DU325 induces differentiation of HL-60 promyelocytes. As a proof of cellular differentiation, the expression of AML blast and leukemia stem cell marker CD33 decreased (A). Matured myeloid cell marker CD11b elevated on the cell surface detected by flow cytometry (B). Due to maturation, the myeloperoxidase (MPO) activity of HL-60 cells increased upon treatment after $48 \mathrm{~h}(\mathrm{C})$. Cells were assayed as described in the Materials and Methods Section 4.12.4. for CD33 and CD11b immunostaining, and 4.11. for the MPO activity. Data are shown as arithmetic mean values \pm standard deviation from triplicate experiments. Statistical significance was calculated in relation to untreated cells and set to ** $p<0.01, * * * 0<0.001$.

\subsection{Differentiation of HL-60 Cells Is Followed by Apoptotic Cell Death}

The cytotoxic effect of DU325 on HL-60 cells was published with $\mathrm{IC}_{50}$ : $66 \mathrm{nM}$ (half maximal inhibitory concentration) and the effect relied on apoptosis not necrosis confirmed by the exclusive AnnexinV/propidium iodide staining [21]. Since Doyle at al. published earlier that induction of differentiation of HL-60 cells is accompanied by apoptotic cell death [57], we further elucidated the effect of DU325 on the viability of HL-60 cells. The RealTime-Glo ${ }^{\mathrm{TM}}$ MT Cell Viability Assay detects the reduction of Nanoluc ${ }^{\circledR}$ substrate by metabolic active cells [58], it revealed that albeit DU325 negatively affects cell viability, this is an asynchronous process not causing a simultaneous cell death in all cells (Figure 5A). The luminescent signals (cps = count per seconds) of metabolically active cells to $1 \mu \mathrm{M}$ DU325 treatment were $3.31 \times 10^{4}$ vs. $5.27 \times 10^{4}$ untr. (untreated) after $24 \mathrm{~h}(p<0.001) ; 3.4 \times 10^{4} \mathrm{vs}$. $1.114 \times 10^{5}$ untr. after $48 \mathrm{~h}(p<0.001) ; 2 \times 10^{4}$ vs. $1.64 \times 10^{5}$ untr. after $72 \mathrm{~h}(p<0.001)$. The decrease of the mitochondrial membrane potential (MMP) was measured by the JC-1 assay. The early treatment with $5 \mu \mathrm{M}$ DU325 induced a moderate depolarization of the mitochondria in $14.2 \pm 0.9 \%$ of cells vs. in $7.5 \pm 1.1$ untreated (steady state) cells after $4 \mathrm{~h}(p<0.01)$ (Figure 5B and Figure S4). The disturbance of the mitochondrial homeostasis was shown after $24 \mathrm{~h}$ by the increase of cells with depolarized mitochondria in $21,43,44$, and $66 \%$ of the cells treated with $40 \mathrm{nM}, 200 \mathrm{nM}, 1 \mu \mathrm{M}$, and $5 \mu \mathrm{M}$ DU325, respectively $(p<0.001)$ (Figure 5B and Figure S4). Next, we studied that the cell death following the differentiation of HL-60 cells is caspase-dependent or independent. We assayed the percentages of cells bearing cleaved active caspase- 3 by flow cytometry and showed a gradual increase on a dose and time dependent manner (Figure $5 \mathrm{C}$ and Figure S5). After $24 \mathrm{~h}$ of administration of $1 \mu \mathrm{M}$ or $5 \mu \mathrm{M}$ DU325 induced the percentage of active caspase-3 positive cells at peaks $44.6 \pm 0.23(p<0.001)$ or 49.7 $\pm 1.13(p<0.001)$ vs. untreated $7.5 \pm 0.21$. The substrate of caspase-3, Z-DEVD-aLuc was cleaved by the lysates of HL-60 cells treated with 200 nM DU325 measured as $2227 \pm 156$ vs. $948 \pm 45$ cps untr. $(p<0.001)$ after $24 \mathrm{~h}$ (Figure 5D). The distribution of cell cycle phases and the percentages of 
hypodiploid cells, as a final stage of apoptosis with the internucleosomal degradation of the DNA was measured by flow cytometry. The ModFit software was used for gating on the intact cells in the FL2-A/FL2-W dot plots and for the quantitation of the percentages of cells in different cell cycle phases. Our drug candidate led to the accumulation of cells in G2/M at the expense of G0/G1 in the case of $200 \mathrm{nM}(12.6 \pm 0.67 \%, p<0.001)$ and $1 \mu \mathrm{M}(11.2 \pm 1.52 \%, p<0.001)$ treatment vs. untreated $(4.2 \pm 0.05$ $\%$ ) (Figure 5E and Figure S6). The highest concentration applied, $5 \mu \mathrm{M}$ DU325 reduced the percentages of cells in the S-phase $(17.06 \pm 1.59$ vs. $32.5 \pm 0.13$ untreated, $p<0.001)$ parallel with the accumulation of G2/M (16.9 \pm 0.49 vs. $4.2 \pm 0.05$ untreated, $p<0.001)$ (Figure 5D). The sub-G1 population with degraded DNA, as a final apoptotic step, increased in a concentration and time dependent manner with $21.97 \pm$ $0.97 \%(200 \mathrm{nM}, p<0.001), 37.63 \pm 1.04 \%(1 \mu \mathrm{M}, p<0.001), 42.3 \pm 1.13 \%(5 \mu \mathrm{M}, p<0.001)$ vs. untreated $(6.2 \pm 0.66 \%)$, respectively (Figure 5F). Finally, the leakage of the LDH (lactate dehydrogenase) into the supernatant was measured as a sign of compromised plasma membrane integrity of late apoptotic cells [59]. We could detect LDH in the media even after treatment with $40 \mathrm{nM}$ DU325 (2.6-fold increase, $p<0.01$ ) for $72 \mathrm{~h}$ (Figure $5 \mathrm{G}$ ).

A

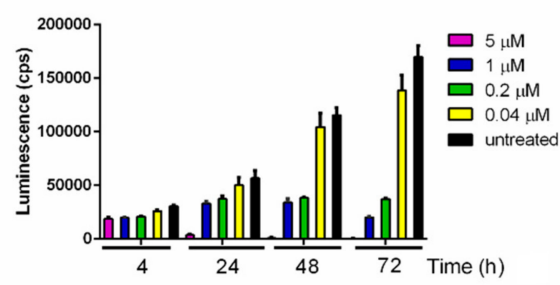

C

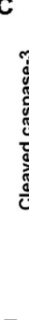

$\mathrm{E}$
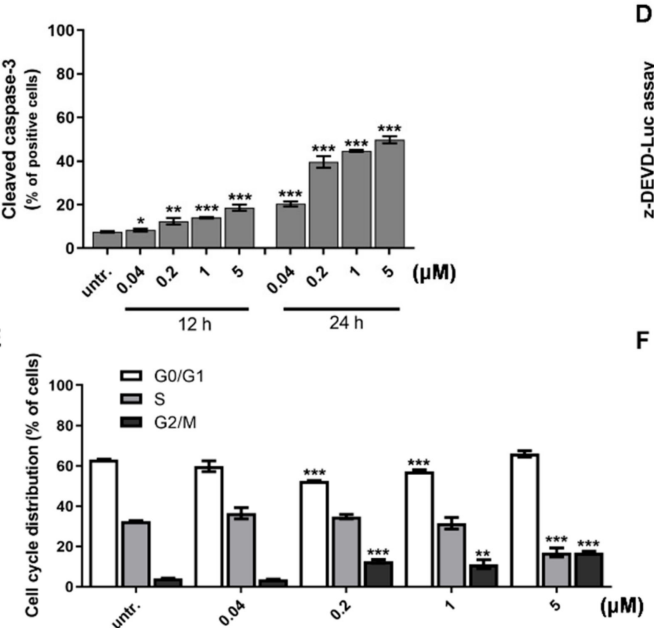

B
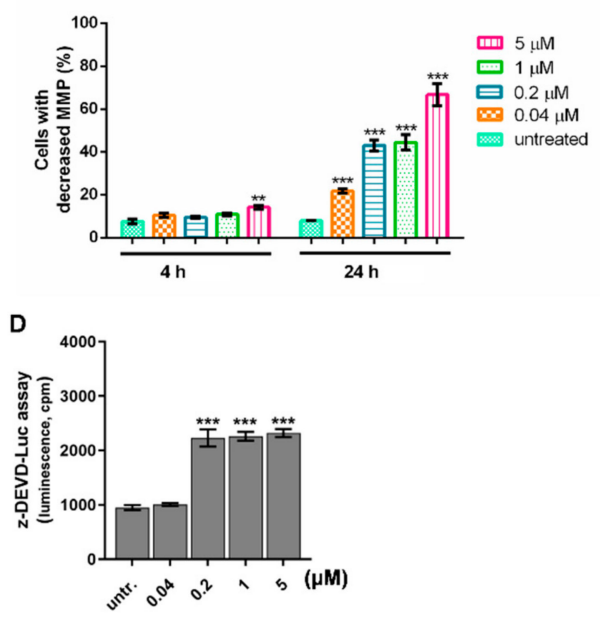

$\mathbf{F}$

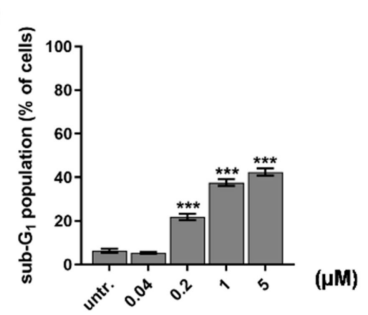

G

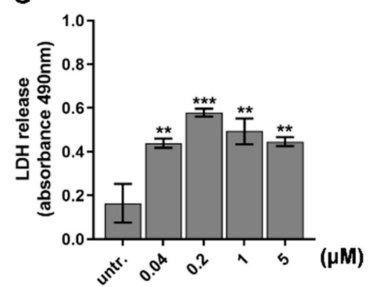

Figure 5. Differentiation of promyelocytic leukemia cells is followed by apoptotic cell death. Differentiation of HL-60 cells was accompanied by cell death detected by RealTime-Glo ${ }^{\mathrm{TM}}$ MT Cell Viability Assay (A). The depolarization of the mitochondrial membrane potential (MMP) (B), activation of caspase-3 (C), and the cleavage of Z-DEVD-aLuc (D) were observed after $24 \mathrm{~h}$. Cell cycle was arrested in G2/M detected after $72 \mathrm{~h}$ incubation (E). Finally, as a proof of massive cell death, we showed both the appearance of the hypodiploid apoptotic cells in the sub-G1 population (F) and the leakage of the lactate-dehydrogenase (LDH) into the supernatant $(\mathrm{G})$ after $72 \mathrm{~h}$ incubation. Data are shown as arithmetic mean values \pm standard deviation from triplicate experiments. Statistical significance was calculated in relation to untreated cells and set to ${ }^{*} p<0.05,{ }^{* *} p<0.01,{ }^{* * *} p<0.001$.

\subsection{DU325 Induces Differentiation and Apoptosis of Human Primary AML Cells}

Although HL-60 cells serve as a popular model of human AML in thousands of publications until now, these cells bear the limitations of cell line models such as lab to lab variations caused by genetic drift (HL-60 cell are cultured ex vivo from 1977), possible infection with Mycoplasma and maximum representing only one, the host patient's condition. In order to validate the differentiating effect of our 
imidazo[1,2-b]pyrazole-7-carboxamide derivative on AML cells, human primary bone marrow aspirate cells were treated from patients diagnosed with AML. Here, we addressed to demonstrate two case studies of human AML cells treated ex vivo, because both the pharmacodynamics and pharmacokinetics of DU325 should be clarified during future pre-clinical studies to design in vivo experiments.

The percentage of CD33 positive human 'AML1' patient-derived bone marrow aspirate cells dropped from $86 \%$ to $30.6 \pm 0.7,(p<0.001)$ and the percentage of CD11b cells increased from $4 \%$ to $12.6 \pm 1.4, p<0.05$ ) upon $200 \mathrm{nM}$ DU treatment for $48 \mathrm{~h}$ (Figure 6A,B).

A

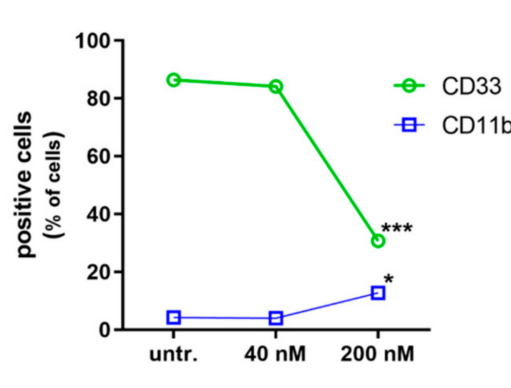

C

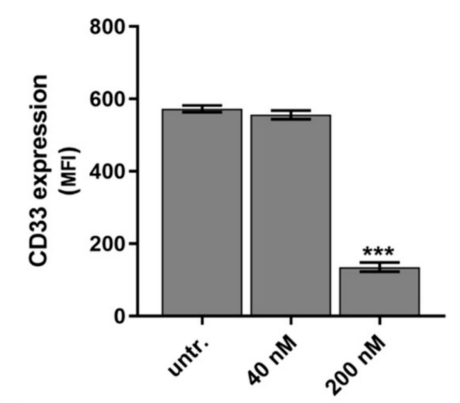

E

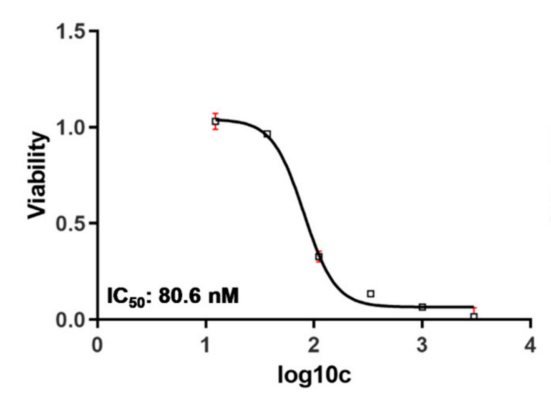

$\mathbf{F}$
B
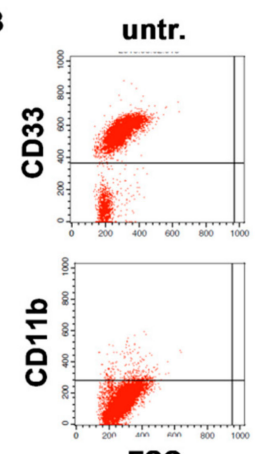

FSC
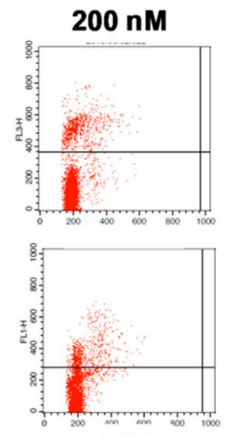

FSC
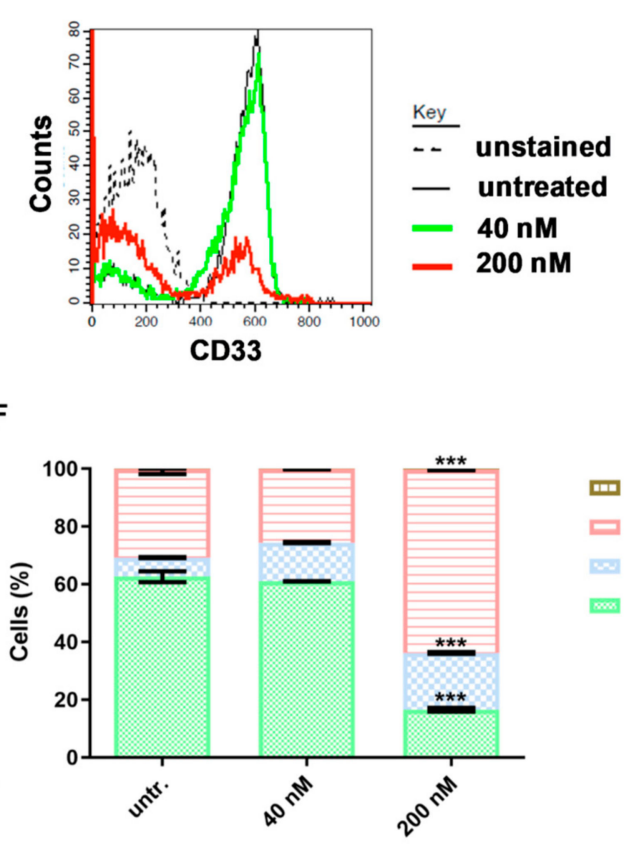

mannV-/PI+

$\square \mathrm{AnnV+/PI+}$

annV+/PI-

AnnV-/PI-

Figure 6. The human 'AML1' patient-derived bone marrow aspirate cells responded to DU325 with differentiation-coupled apoptosis. The loss of the percentage of $C D 33$ positive and an increase of $C D 11 \mathrm{~b}$ positive cells were assayed by flow cytometry (A) and (B) after 48 incubation with $200 \mathrm{nM}$ DU325. The median fluorescent intensity (MFI) proportional with CD33 expression on the cells also decreased by $200 \mathrm{nM}$ DU325 (C) and (D). The resazurin viability assay determined $\mathrm{IC}_{50}$ value of DU325 on the primary human patient-derived 'AML1' cells after $72 \mathrm{~h}$ treatment of $80.6 \mathrm{nM}$. Concentrations of DU325 were as follows, $3 \mu \mathrm{M}, 1 \mu \mathrm{M}, 333 \mathrm{nM}, 111 \mathrm{nM}, 37 \mathrm{nM}$, and $12 \mathrm{nM}$ (E). The combined Annexin V and propidium iodide (AnnV/PI) flow cytometry staining showed an increase of both AnnV+/PI- early and AnnV+/PI+ late apoptotic cells after treatment with $200 \mathrm{nM}$ DU325 for $48 \mathrm{~h}(\mathbf{F})$. Data are shown as arithmetic mean values \pm standard deviation. Statistical significance was set to ${ }^{* * *} p<0.001$.

The density of CD33 marker on the 'AML1' cells showed 65\% reduction $(p<0.001)$ after treatment with DU325 detected by flow cytometry (Figure 6C,D). Similarly to the HL-60 cell line, the viability of human primary 'AML1' cells was hampered by DU325, with $80.6 \mathrm{nM} \mathrm{IC} 50$ value (Figure 6E). 
Differentiation-coupled apoptosis was detected by AnnV/PI (Annexin V/propidium iodide) flow cytometry staining showing $63.5 \pm 0.28 \%$ late apoptotic AnnV+/PI+ cells vs. $16.4 \pm 0.62 \%$ untreated after $200 \mathrm{nM}$ DU325 administration for $48 \mathrm{~h}$ (Figure 6F).

In order to further explore the effect of DU325, cells of another case of human primary AML, the 'AML2' were treated and analyzed by single cell resolution mass cytometry. The multiparametric immunophenotyping was carried out by the simultaneous labeling with fifteen metal-tag labeled antibodies. The number of singlets (single cell events) analyzed by CyTOF (cytometry by time-of-flight) were as follows, 380,906 for untreated; 358,557 for $40 \mathrm{nM}$ DU325 treated; and 309,345 for $200 \mathrm{nM}$ DU325 treated. The viability of 'AML2' cells was assessed by the uptake of ${ }^{195} \mathrm{Pt}$ cisplatin analyzed by CyTOF. The imidazo[1,2-b]pyrazole-7-carboxamide derivative, DU325 reduced the viability of patient derived 'AML2' cells from 86.27 to $62.18 \%$ applied at $200 \mathrm{nM}$ for $48 \mathrm{~h}$ (Figure S7). Markers of AML such as CD7 (T-cell Leukemia Antigen), CD33, CD206 (mannose receptor C type 1, MRC1), and CD38 (ADP-Ribosyl Cyclase 1) were included in the antibody panel. The percentage of these subpopulations was determined by manual gating (Figure 7A) and visualized on a radar plot (Figure 7B). The most potent effect of DU325 was at $200 \mathrm{nM}$ decreasing the following subpopulations of CD7+ cells from 71.17 to $37.31 \%$, CD 33 + cells from 88.29 to $59.63 \%$, CD7+/CD33+ cells from 66.9 to $30.38 \%$, CD206+ cells from 71.45 to $35.39 \%$, and CD38 bright 80.33 to $47.12 \%$ (Figure $7 \mathrm{~A}, \mathrm{~B}$ ). The trajectories of the radar plot delineate the expression profile of the markers of the patient-derived AML2 cells treated by $40 \mathrm{nM}, 200 \mathrm{nM}$ DU325 or left untreated. The percentage of the AML2 cells gated by the following markers; CD45, CD11b, CD38 (all), CD163, CD11c, HLA-DR, CD16, CD19, CD66, CD14, CD3, and CD36 upon $40 \mathrm{nM}$ or $200 \mathrm{nM}$ DU325 treatment is shown in Figure S8. The median metal intensity values proportional with the expression intensities of the proteins on the singlets were as follows; for CD7: 91.69, 75.82, and 12.08; CD33: 123.69, 93.09, and 36; CD206: 33.35, 26, and 13.24, CD38: 843.14, 655.18, and 306.7 as untreated, $40 \mathrm{nM}$ or $200 \mathrm{nM}$ DU325 treated, respectively (Figure 7C). Taken together, we could detect at single cell resolution by mass cytometry that both CD7+, CD33+, $\mathrm{CD} 7+/ \mathrm{CD} 33+, \mathrm{CD} 206+$, and CD38 ${ }^{\text {bright }}$ human primary bone marrow aspirate cells were the most sensitive to the ex vivo treatment with our drug candidate DU325. 


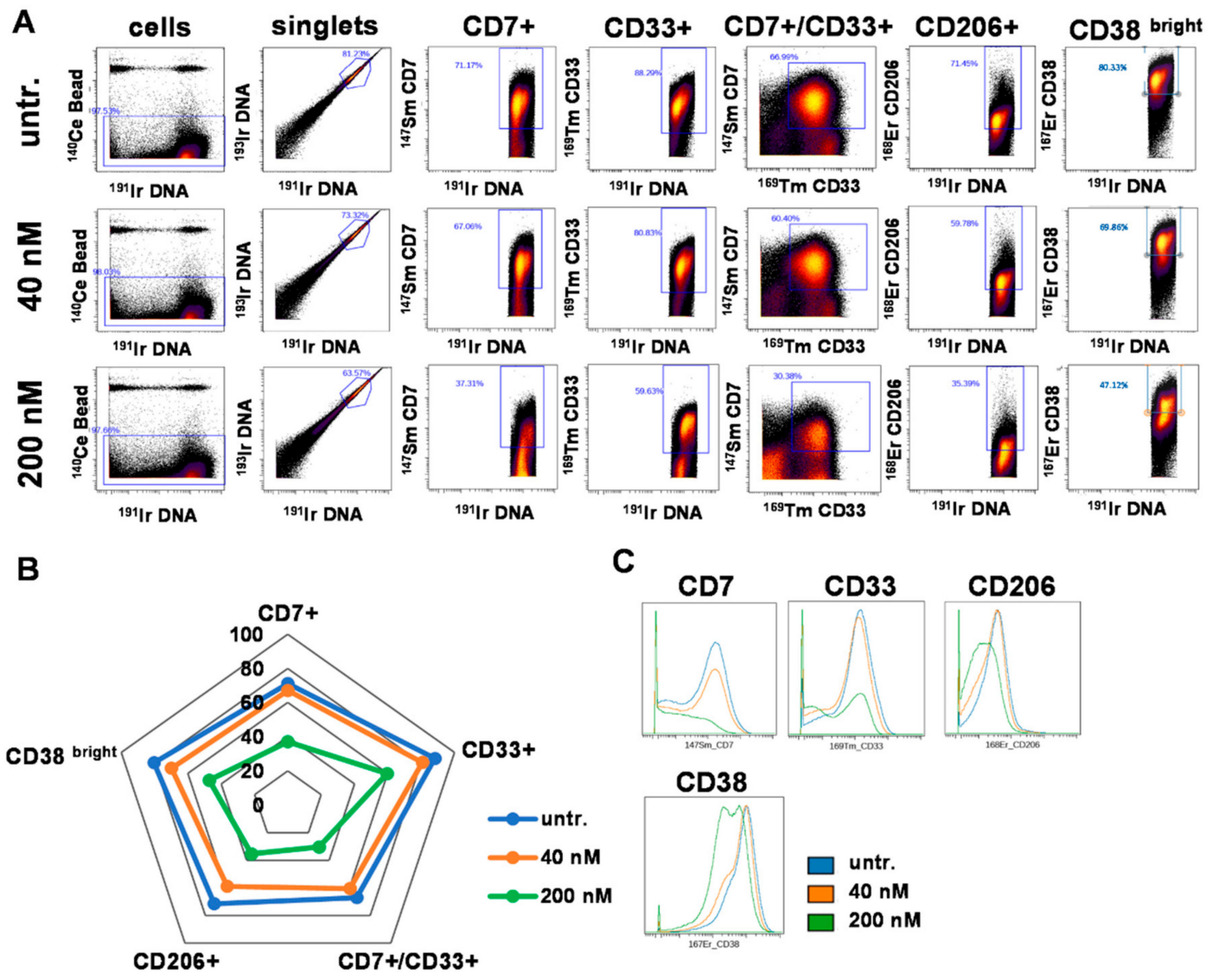

Figure 7. The percentage of CD7+, CD33+, CD7+/CD33+, CD206+, and CD38 bright human AML2, patient-derived bone marrow aspirate cells decreased after the treatment with DU325 ex vivo. Mass cytometry was used for multiparametric immunophenotyping of AML2 patient-derived cells treated by DU325 for $48 \mathrm{~h}$. Gating strategy is presented to define single cells and sub-populations of AML cells (A). Gating strategy for 11 additional subpopulations can be found in Figure S8. The pentagram of the population trajectories (B) shows the decrease of the percentages of CD7+, CD33+, CD7+/CD33+, CD206+, and CD38 bright AML2 cells treated with $40 \mathrm{nM}$ (orange) or $200 \mathrm{nM}$ DU325 (green) ex vivo for $48 \mathrm{~h}$. The overlay of the histograms demonstrates the lower expression of CD7, CD33, CD206, and CD38 followed by DU325 treatment in nanomolar range (C).

The $t$-distributed stochastic neighbor embedding ( $\mathrm{SSNE}$ ) algorithm enables the multidimensional analysis of the cells simultaneously taking into account all of fifteen antibodies in the antibody panel for each event at single cell resolution. The cell relatedness of cells with common marker expression is shown by the proximity of these cells in the islands of the visualization of stochastic neighbor embedding (viSNE) graphs. The coloration is proportional to the expression intensity (blue $=$ low, red $=$ high) for each marker separately [60]. This unsupervised analysis verified that CD7+, CD33+, CD206+, and CD38 bright cells were the most sensitive to DU325 and these cells represent partially overlapping subpopulations of AML2 human primary bone marrow aspirate cells (Figure 8). The tSNE analysis of the other eleven markers of the antibody panel showed strong HLA-DR expression, CD45 dim positivity, and weak CD11c+ intensity, with almost the absence of CD163+, CD11b+, CD66+, CD36+, $\mathrm{CD} 16+, \mathrm{CD} 14+, \mathrm{CD} 19+$, and CD3+ populations (Figure S9). 

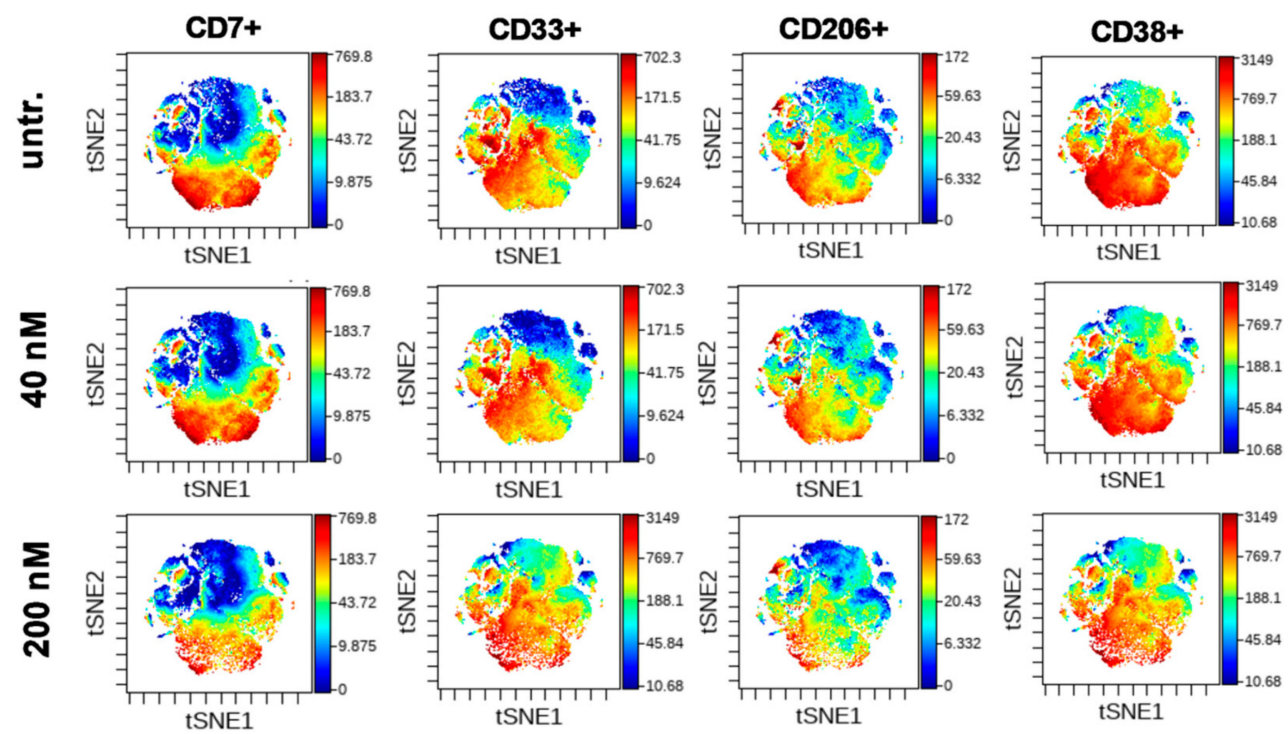

Figure 8. The most sensitive cells to DU325 treatment were CD7+, CD33+, CD206+, and CD38 bright . The multidimensional viSNE plots of mass cytometry experiments illustrate the expression intensity of CD7, CD33, CD206, and CD38 markers showing a partial overlay, common marker expression of these subpopulations of human AML2 patient-derived cells. The coloration is proportional to the expression intensity (blue $=$ low, red $=$ high). The AML2 cells were treated with $40 \mathrm{nM}$ or $200 \mathrm{nM}$ DU325 ex vivo for $48 \mathrm{~h}$. The viSNE plots of the rest, the other 11 markers can be found in Figure S9, the list of all antibodies used for mass cytometry can be found in Section 4.13.

\subsection{DU325 Treatment Ex Vivo Reduced Both Monocytic and Granulocytic Splenic MDSCs from the} 4T1 Murine Breast Cancer Model

We have previously reviewed the contribution of MDSCs to the tumor microevolution $[23,28]$ and showed the expansion of these immature myeloid cells in the spleen of $4 \mathrm{~T} 1$ breast cancer bearing mice [29]. Here, we addressed to investigate the effect of DU325 treatment on the viability of these MDSCs ex vivo. The resazurin viability assay showed three times sensitivity of splenocytes from $4 \mathrm{~T} 1$ tumor bearing mice with $70.64 \mathrm{nM} \mathrm{IC}_{50}$ value compared to naive cells $\left(\mathrm{IC}_{50}: 221.9 \mathrm{nM}\right)$ (Figure 9A). The percentage of late apoptotic (AnnV+/PI+) cells from tumor-bearing mice increased upon DU325 treatment to $31 \pm 1.6 \%$ vs. $7.6 \pm 3.7 \%(p<0.001)$ untreated, and it was a significant increase also compared to DU325 treated naive splenocytes with $17.08 \pm 4.6 \%(p<0.001)$ (Figure 9B). After the incubation with DU325 both monocytic CD11b+/Ly6C+ and granulocytic CD11b+/Ly6G MDSCs were reduced to six times less percentage $(p<0.001)$. The gating strategy for monocytic CD11b+/Ly6C + and for granulocytic CD11b+/Ly6G MDSCs can be found in Figure S10 and in Figure S11, respectively. 
A

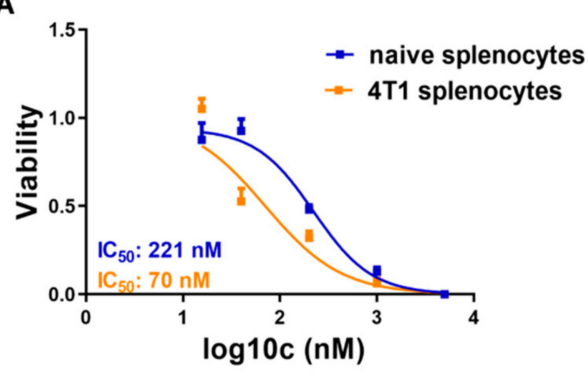

B

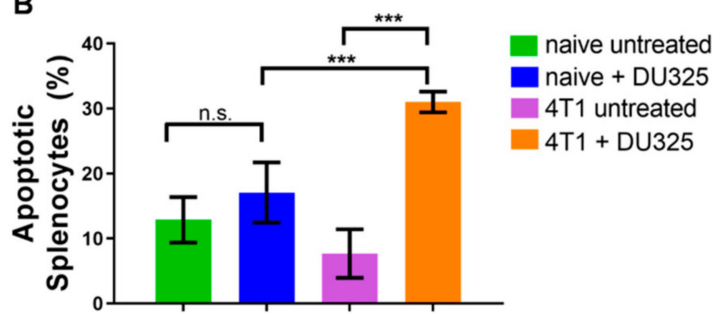

C

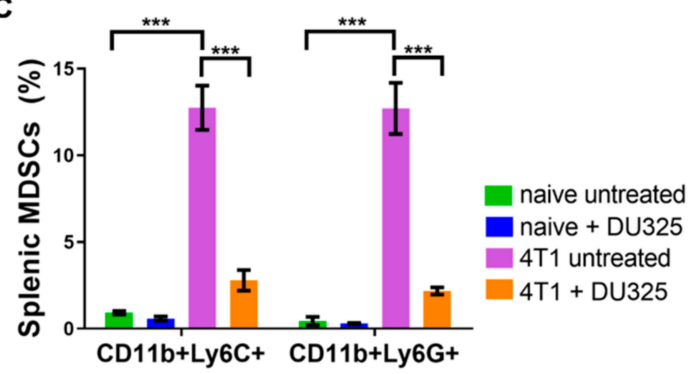

Figure 9. DU325 treatment hampered the viability of splenocytes, both CD11b+/Ly6C+ and CD11b+/Ly6G+ splenic MDSCs. Cells were treated with $5 \mu \mathrm{M}, 1 \mu \mathrm{M}, 200 \mathrm{nM}, 40 \mathrm{nM}$, and $20 \mathrm{nM}$ DU325 for $72 \mathrm{~h}$ and assayed by the resazurin viability test (A). The percentage of AnnV+/PI+ late apoptotic cells was increased after treatment with $200 \mathrm{nM}$ DU325 for $72 \mathrm{~h}$ (B). The immunofluorescent staining showed a reduction of both monocytic CD11b+/Ly6C+ and granulocytic CD11b+Ly6G+ MDSCs treated with $200 \mathrm{nM}$ DU325 for $72 \mathrm{~h}$ ex vivo (C). Data are shown as arithmetic mean values \pm standard deviation from triplicate experiments. Statistical significance was set to ${ }^{* * *} p<0.001$.

\section{Discussion}

Multi-target drugs changing cancer cell homeostasis via modulating apoptotic, differentiation, and metabolic pathways have been applied to treat different malignancies [61]. However, novel agents acting via different mechanisms were approved by the FDA to manage AML and have been recently reviewed [8,62], the overall survival of AML remained poor, especially in the elderly. Another pathophysiologic condition is the expansion of immature myeloid cells, such as MDSCs with potent immunosuppression in solid malignancies. We have previously reviewed the inventory of drugs targeting these MDSCs and discussed differentiation induction therapy as an already proved concept by the administration of vitamin D3 or ATRA [28]. However, reducing MDSCs as a part of supportive immunotherapy still is not implemented in the clinical routine. Along SAR optimization we have designed and synthetized a 74 member library of imidazo[1,2-b]pyrazole-7-carboxamides with apoptotic effect on HL-60 cells [20,21]. In order to elucidate the mechanism of action and target immature myeloid cells of AML or MDSCs, our lead imidazo[1,2-b]pyrazole-7-carboxamide derivative, DU325 was tested on HL-60 or human primary AML bone marrow aspirate cells, or on the viability of murine $4 \mathrm{~T} 1$ breast cancer-derived splenic MDSCs ex vivo.

Using the HL-60 model cell line, we showed that DU325 drives early survival signals. The percentage of pERK $^{\text {bright }}$ positive cells (phosphorylation of ERK1/2 at Thr202/Tyr204) was increased after $2 \mathrm{~h}$ of treatment with DU325 (Figure 10). In agreement with this, the involvement of ERK1/2 phosphorylation in cell growth and myeloid differentiation was previously published by others upon administration of ATRA [36], G-CSF and M-CSF [39], or Xenospontine [40]. There was an increase in the percentage of antiapoptotic Bcl-xl ${ }^{\text {bright }}$ cells in line with previous reports showing ERK dependent survival of Bcl-xl ${ }^{\text {bright }} \mathrm{HL}-60$ cells [41,42]. The inhibition of apoptosis or the early cell survival was accompanied with the increase of pAkt ${ }^{\text {bright }}$ (Ser473) HL-60 cells after DU325 treatment, which is known to contribute to the NF-kB-driven induction of Bcl-xl [43]. Next, we investigated the accumulation of the hematopoietic cell specific Vav1 protein, one of the master regulators of myeloid leukemia cell differentiation [37]. The Vav1 coordinates cellular maturation via its versatile 
functions such as GEF activity, affecting cell motility, and morphology via influencing reorganization of actin cytoskeleton and modulating gene expression via interacting with transcription factors, ribonucleoprotein complexes $[45,63]$. We showed the accumulation of both Vav1 and p174-Vav1 (Tyr174) in the cytoplasm and nuclei and that was associated with changes in gene expression of AP-1 TF complex leading to increased granularity and loss of CD33 expression. It has been known that both ERK1/2 [51,52], and Vav1 can affect AP-1 expression [53,54]. The expression of the members of AP-1 TF complex: FOS, JUN, JUNB, and JUND were gradually increased after DU325 stimulation. The expression of other transcription factors was investigated such as Spl1 (Transcription factor PU.1), RUNX1 (Runt-related transcription factor 1), CEBPA (CCAAT/enhancer binding protein alpha), GABP1 (GA-binding protein subunit beta-1), and IRF1 (Interferon regulatory factor-1), but these were not differentially expressed upon DU325 treatment. Brugnoli et al. found that Vav1 can be recruited to the promoter to drive the expression of CD11b [48], and both the members of AP-1 TF may play in the subsequent steps driving cellular differentiation. However, we did not addressed chromatin immunoprecipitation (ChIP) to isolate target genes of AP-1 TF or Vav1 ribonucleoprotein complexes, as we focused on the interrogation of DU325 caused phenotypic changes at single cell level. Differentiated HL-60 cells increased their granularity detected on SSC-FSC dot plots, remained nonadherent and short lived, decreased CD33 and increased CD11b level and MPO activity suggesting granulocytic differentiation. The HL-60 cells poorly, only in 5\% express CD34 that is why it was not monitored [64]. The proposed role of the survival pathways (ERK phosphorylation, Bcl-xl induction, and Akt phosphorylation) in the induction of Vav1 and AP-1 is the guidance and orchestration of cellular differentiation of the studied immature myeloid cells (Figure 10) [65,66].

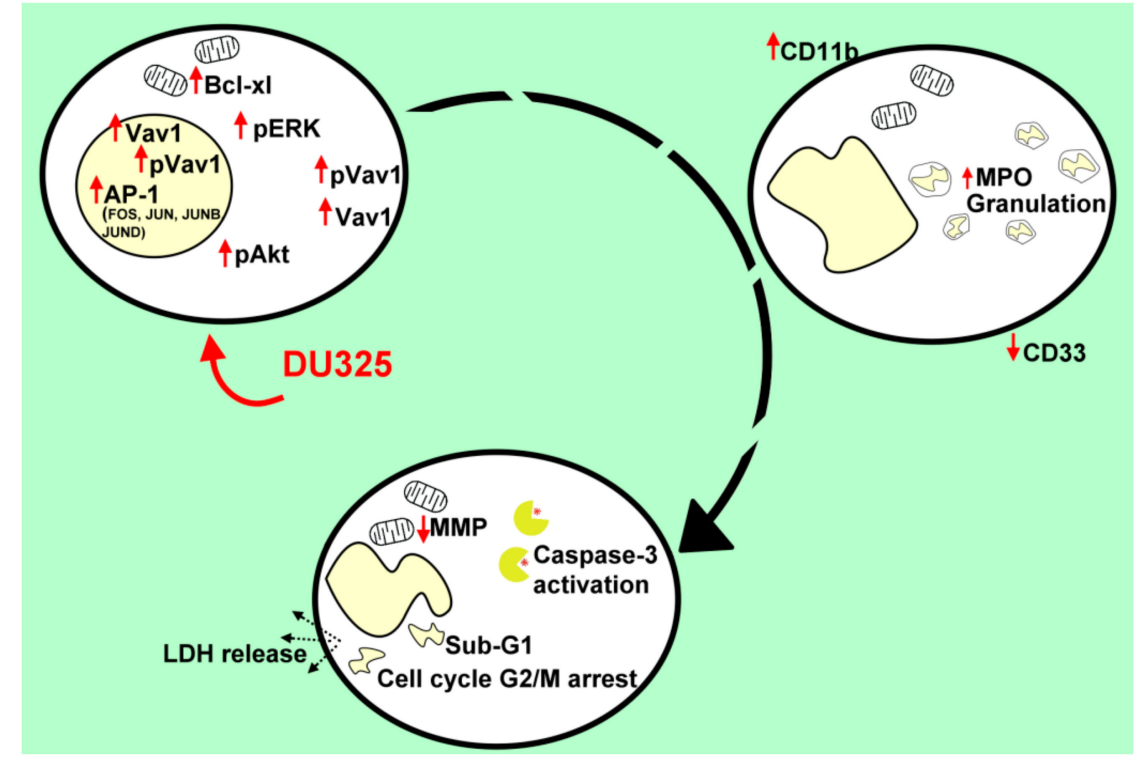

Figure 10. The series of events followed after the treatment of HL-60 cells with DU325. We obtained ERK phosphorylation as an early survival response to treatment followed by the increase of the percentage of the Bcl-xl ${ }^{\text {bright }}$ and pAkt ${ }^{\text {bright }}$ cells. The induction of Vav1, pVav1, and the AP-1 complex is a driver of cellular differentiation; FOS, JUN, JUNB, and JUND were elevated on a concentration and time-dependent manner. As a proof of granulocytic differentiation, the cells remained nonadherent and the expression of CD33 decreased; the granularity, CD11b expression, and MPO activity of HL-60 cells increased upon treatment. Finally, viability of HL-60 cells was hampered shown by the depolarization of mitochondria, activation of caspase-3, G2/M cell cycle arrest, appearance of the sub-G1 population, and the leakage of the lactate-dehydrogenase into the supernatant.

Finally, differentiation-induced apoptosis was assayed on HL-60 cells upon DU325 administration because it was previously published that maturation of HL-60 cells spontaneously leads to apoptosis in these cells $[55,57,67]$. Maianski et al. published that the major role of the mitochondria of the matured 
neutrophils is to drive the apoptotic cell death [68]. Indeed, we showed the loss of viability in a real-time assay and the depolarization of the mitochondria driving the intrinsic pathway of apoptosis. Additionally, we showed the subsequent steps of apoptosis, activation of caspase-3, cleavage of Z-DEVD-aLuc, increase of hypodiploid sub-G1 population, and leakage of LDH into the supernatant after $72 \mathrm{~h}$ of treatment (Figure 10). The effect of DU325 was dissected in HL-60 cells bearing c-myc proto-oncogene amplification as a canonic model of human AML cells [11].

We have further investigated human primary bone marrow aspirate cells form different AML patients, as two different case studies, because the AML sub-types greatly vary regarding the genetic mutations. The treatment of primary AML cells was performed ex vivo. However, we could show the loss of CD33 and increase of CD11b on AML1 cells followed by apoptosis with $80.6 \mathrm{nM}$ $\mathrm{IC}_{50}$ value. The response of patient-derived AML2 cells was monitored by that state-of-the-art single cell mass cytometry providing multiplex immunophenotyping and complex bioinformatic analysis. Performing immunostaining with 15 antibodies revealed the most sensitive subpopulations to DU325 treatment, namely, CD7+, CD33+, CD7+/CD33+, CD206+, and CD38 bright shown by manual gating and unsupervised viSNE analysis. The CD7, CD33, and CD38 are well-known therapeutic targets of AML [69-71]. Although the mannose receptor C type 1 (MRC1), the CD206 has been described as a marker of M2, alternatively polarized macrophages or M2-like monocytes with the co-expression of CD14 and CD163 [23], we detected CD206 cells distinct from CD14+ and CD163+ cells as it shown in the viSNE maps. Using single cell RNA sequencing and Cancer Genome Atlas data of 179 AML patients, Galen et al. found that higher expression of CD206+ was correlated with poor survival offering CD206 as a good target in AML [72].

Based on our results and on the fact that differentiation of immature APL or AML cells increase the sensitivity to chemotherapeutic drugs $[73,74]$ novel studies should be initiated to examine the efficacy of the combination of differentiating agents with existing anticancer drugs.

Another pathologic condition is the expansion of immature myeloid cells, such as MDSCs in the bone marrow and tumor microenvironment of solid malignancies [75]. We have previously reviewed the pharmaceutical drugs or therapeutic efforts for the selective ablation of these MDSCs, inhibiting their recruitment or limiting their functions [28]. Using our imidazo[1,2-b]pyrazole-7-carboxamide we could induce the apoptosis of both CD11b+/Ly6C+ monocytic and CD11b/Ly6G+ granulocytic MDSCs isolated from the spleen of 4T1 tumor bearing mice. Maturation of MDSCs can be targeted not only in tumor but in sepsis also. Due to the high mortality of sepsis there is an unmet high medical need for novel therapies. It has been published that myeloid-derived cells emerge in septic patients suppressing antigen-driven T cell proliferation, Th1/Th2 cytokine production contributing to higher prevalence of nosocomial infections [76]. Monocytic MDSCs are accumulated in all septic patients whereas granulocytic MDSCs are increased in gram positive cases [77]. It has been published that matured MDSCs lose their inherent immunosuppressive phenotype that could solve the dormant state of the antigen specific immune response in sepsis [78].

However, we have shown that both AML and MDSCs differentiate and dye by apoptosis after the treatment with DU325, although these cells may differ in the underlying molecular mechanisms of differentiation. These molecular pathways need further investigation to reveal. Taken together, our imidazo[1,2-b]pyrazole-7-carboxamide derivative is an effective lead compound at nanomolar range to target immature myeloid cells and it is offered for future pre-clinical studies including pharmacodynamics, pharmacokinetics, and safety.

\section{Materials and Methods}

\subsection{Ethical Statement}

The animal experiments were performed in accordance with animal experimentation and ethics guidelines of the EU (2010/63/EU). Experimental protocols were approved by the responsible 
governmental agency (National Food Chain Safety Office) in possession of an ethical clearance XXIX./128/2013 (2013).

Participant informed consent was obtained prior surgical intervention. The collection of human samples was complied with the Guidelines of the Helsinki Declaration. The isolation of human AML cells was approved by the National Institute of Environmental Health under the 47226-7/2019/EÜIG (2019) ethical license.

The patient AML1 (61-year-old male) was diagnosed with acute myeloid leukemia with cup-like morphology. Laboratory tests showed that bone marrow aspirate cells were in $92 \%$ myeloid blasts and $\mathrm{CD} 117^{-} / \mathrm{CD} 34^{-} / \mathrm{D} 13^{-} / \mathrm{CD} 33^{\text {bright }} / \mathrm{cyMPO}+/ \mathrm{HLA} \_\mathrm{DR}-/ \mathrm{CD} 38+, 58 \%$ positive for CD56 and negative for monocyte markers CD64, CD14, CD300e, and cyFXIII; negative for granulocyte markers CD15, CD16, CD10, and CD11b; and negative for T cell markers CD4, CD7, and CD2. Cytogenetic status was the following, karyotype: normal; FLT3: wild type; CEBPA: wild type; NPM1: insertion (4 nucleotides = nts) in the 12th exon.

The patient AML2 (24-year-old male) was diagnosed with acute myeloid leukemia. Laboratory tests showed that bone marrow aspirate cells were in $85 \%$ myeloid blasts, these were in $71 \%$ CD117+/CD34+ which cells were CD13+/CD33+/cyMPO+/HLA_DR+/CD38+/CD4 ${ }^{-} / \mathrm{CD}_{11 b^{-}}$and in $84 \% \mathrm{CD} 7+$, in $14 \%$ $\mathrm{CD} 56+$, in 14\% CD15+, in 12\% cyFXIII+. Cytogenetic status was the following, karyotype: normal; FLT3: wild type; CEBPA: duplication (24 nts), insertion ( $3 \mathrm{nts})$, point mutation (c.1119A>C), NPM1: wild type.

\subsection{Cell Culture and Isolation of Human AML Cells}

The HL-60 acute promyelocytic leukemia and the mouse mammary carcinoma 4T1 cells were purchased from the American Type Culture Collection (ATCC, Manassas, WV, USA) maintained in Roswell Park Memorial Institute 1640 medium (RPMI-1640) 10\% FCS (Gibco, Thermo Fisher Scientific, Waltham, MA, USA) using tissue culture dishes (Corning Life Sciences, Corning, NY, USA). The $\mathrm{pH}$ of the cell culture media was controlled to be between 7.2 and 7.4 prior to use. The medium was supplemented with $2 \mathrm{mM}$ GlutaMAX, $100 \mathrm{U} / \mathrm{mL}$ penicillin, and $100 \mu \mathrm{g} / \mathrm{mL}$ streptomycin (Life Technologies, Carlsbad, CA, USA) before use. Cells were passed every three days and placed in a humidified incubator at $37{ }^{\circ} \mathrm{C} 5 \% \mathrm{CO}_{2}$ (Sanyo, Osaka, Japan).

The aspiration of ten $\mathrm{ml}$ bone marrow of AML patients from the pelvis was carried out upon a clinical visit after the signed informed consent of the patients into EDTA Vacutainers (Beckton Dickinson, Franklin Lakes, NJ, USA). Samples were centrifuged $1400 \mathrm{rpm} 5 \mathrm{~min}$, the supernatant was removed. Red blood cell lysis was carried out by the incubation of cells with $5 \mathrm{~mL}$ ACK $(0.155 \mathrm{M}$ $\mathrm{NH}_{4} \mathrm{Cl}, 10 \mathrm{mM} \mathrm{KHCO} 3,0.1 \mathrm{mM} \mathrm{Na} 2 \mathrm{EDTA}, \mathrm{pH} 7.3$, Sigma-Aldrich) solution for $5 \mathrm{~min}$. Samples were loaded on cell strainer (70 $\mu \mathrm{m}$ in pore size) and washed by $20 \mathrm{~mL}$ PBS. Cells were counted using Bürker chamber and trypan blue viability dye (Thermo Fisher Scientific) and plated for the treatment as described in the relevant Sections of Materials and Methods.

\subsection{Isolation of Murine Myeloid-Derived Suppressor Cells}

Female Charles River-derivative BALB/c mice (8-10 weeks old) were purchased from Kobay Ltd., (Ankara, Turkey) and were injected orthotopically with 4T1 breast carcinoma cells $\left(1.2 \times 10^{5}\right.$ cells in 100 $\mu \mathrm{L}$ PBS) or sham injected with $100 \mu \mathrm{L}$ PBS as described previously [29]. The animals had free access to food and water. Biological replicates were analyzed separately from the naive and 4T1 tumor-bearing mice. The weights of the spleens were as follows in the naïve; $99,8,13,14$, and $12 \mathrm{mg}$, and in the tumor-bearing mice; 781, 812, 968, 1350, and $935 \mathrm{~m}$. The weights of the tumors were as follows; $2523,3037,2064,2877$, and $1522 \mathrm{mg}$; the volume of the tumors were as follows; $1272,1329,650,1573$, and $807 \mathrm{~mm}^{3}$ after 28 days from the injection. The volume of the tumor was measured by a caliper and calculated by the following equation; $D \times d^{2} \times 0.5$, where $D=$ major diameter, $d=$ minor diameter as we described previously for the $4 \mathrm{~T} 1$ breast cancer model $[79,80]$. After euthanizing the animals, the spleens were removed and homogenized freshly on cell strainer (70 $\mu \mathrm{m}$ pore size, Merck Millipore) using 
piston of a syringe and sterile PBS. Cells were pelleted by centrifugation $1500 \mathrm{rpm} 5 \mathrm{~min}$. The pellet was resuspended in $5 \mathrm{~mL}$ ACK lysis buffer for $5 \mathrm{~min}$. Samples were loaded on cell strainer $(70 \mu \mathrm{m}$ in pore size) and washed by $20 \mathrm{~mL}$ PBS. Cells were counted using Bürker chamber and trypan blue viability dye (Thermo Fisher Scientific) and plated for resazurin viability assay and immunofluorescent staining upon treatment by imidazo[1,2-b]pyrazole-7-carboxamide derivative in RPMI-1640 media supplemented with 10\% FCS, $25 \mu \mathrm{M} \beta$-mercaptoethanol, $2 \mathrm{mM}$ GlutaMAX, and $100 \mathrm{U} / \mathrm{mL}$ penicillin, $100 \mu \mathrm{g} / \mathrm{mL}$ streptomycin. Cells for flow cytometry were plated into nonadherent Petri dishes (Corning).

\subsection{Treatment by the Imidazo[1,2-b]pyrazole-7-carboxamide Derivative, DU325}

The imidazo[1,2-b]pyrazole-7-carboxamide derivative was synthetized at Avidin Ltd. (Szeged, Hungary) as described previously [20]. The compound was DU325, $N$-(4-aminophenyl)-2-(tert-butyl)-3-(tert-butylamino)-1H-imidazo[1,2-b]pyrazole-7-carboxamide, the structure is available in the reference [21]. The compound was dissolved in DMSO at $10 \mathrm{mM}$ concentration. Dilutions for the treatment of the cells was prepared in RPMI-1640 complete cell culture media as the concentration is described in the corresponding figure legends.

\subsection{Resazurin Viability Assay}

Cell viability was determined by the fluorescent Resazurin assay as described previously [81]. AML1, MDSCs cells (80,000), were seeded into 96-well plates (Corning Life Sciences) in $80 \mu \mathrm{L}$ cell culture media. Effect of DU325 was examined in AML1 cells in concentrations $3 \mu \mathrm{M}, 1 \mu \mathrm{M}, 333 \mathrm{nM}$, $111 \mathrm{nM}, 37 \mathrm{nM}$, and $12 \mathrm{nM}$ in $100 \mu \mathrm{L}$ final volume after $72 \mathrm{~h}$ incubation. Effect of DU325 was examined in mouse splenocytes in concentrations $5 \mu \mathrm{M}, 1 \mu \mathrm{M}, 200 \mathrm{nM}, 40 \mathrm{nM}$, and $20 \mathrm{nM}$ in $100 \mu \mathrm{L}$ final volume after $72 \mathrm{~h}$ incubation. Resazurin reagent (Sigma-Aldrich) was dissolved in PBS (pH 7.4) at $0.15 \mathrm{mg} / \mathrm{mL}$ concentration, sterile filtered $\left(0.22 \mu \mathrm{m}\right.$, Merck Millipore) and aliquoted at $-20^{\circ} \mathrm{C}$. We applied resazurin $20 \mu \mathrm{L}$ stock to $100 \mu \mathrm{L} /$ well culture. After $12 \mathrm{~h}$ incubation at $37^{\circ} \mathrm{C} 5 \% \mathrm{CO}_{2}$ (Sanyo), fluorescence (530 nm excitation $/ 580 \mathrm{~nm}$ emission) was recorded on a multimode microplate reader (Cytofluor4000, PerSeptive Biosytems). Viability was calculated with relation to untreated control cells and blank wells containing media without cells. The $\mathrm{IC}_{50}$ values were calculated by GraphPad Prism ${ }^{\circledR} 5$.

\subsection{RealTime-Glo ${ }^{T M}$ MT Cell Viability Assay}

The HL-60 cells (2000) were seeded into UV-C sterilized opaque 96-well plates (Tomtec, Budapest, Hungary) in $40 \mu \mathrm{L}$ media. RealTime-Glo ${ }^{\mathrm{TM}}$ reagent (Promega) (2X) was added according to the instructions of the manufacturer. The effect of DU325 was examined in concentrations of $5 \mu \mathrm{M}, 1$ $\mu \mathrm{M}, 0.2 \mu \mathrm{M}$, and $0.04 \mu \mathrm{M}$ in final volume $100 \mu \mathrm{L} /$ well. We measured luminescence on a multimode microplate reader (Victor 1430, Wallac, Perkin Elmer) corresponding to live cell number after $1 \mathrm{~min}$ to register the baseline and subsequently samples were measured daily.

\subsection{Z-DEVD-aLuc Caspase Assay}

Cells were treated $\left(1 \times 10^{6} \mathrm{HL}-60\right.$ cells in $1 \mathrm{~mL}$ media) in 24-well tissue culture plates for $24 \mathrm{~h}$ in the concentrations indicated in the graphs and assayed as described previously [82]. Briefly, after $24 \mathrm{~h}$, cells and supernatants were harvested and centrifuged down (3000 rpm, $5 \mathrm{~min}, 4^{\circ} \mathrm{C}$, Eppendorf). After the withdrawal of the supernatant pellet was lysed in $50 \mu \mathrm{L} 1 \mathrm{X}$ Lysis Buffer, stock lysis buffer $5 \mathrm{X}$ (250 mM HEPES, pH 7.4, 25 mM CHAPS, 25 mM DTT, Sigma-Aldrich), stored at $-20{ }^{\circ} \mathrm{C}$, was diluted prior use freshly in sterile water. After resuspending the pellet, we incubated the samples on ice for $15 \mathrm{~min}$. The debris were pelleted by centrifugation $\left(13,000 \mathrm{rpm}, 15 \mathrm{~min}, 4^{\circ} \mathrm{C}\right.$, Eppendorf). We diluted Z-DEVD-aLuc substrate (10 mM stock in DMSO, Avidin Ltd.) in 1X Assay Buffer, stock Assay Buffer 10X (200 mM HEPES, pH 7.4, 1\% CHAPS, $50 \mathrm{mM}$ DTT, $20 \mathrm{mM}$ EDTA) was stored at $-20^{\circ} \mathrm{C}$ and it was diluted prior use freshly in sterile water. The assay was run in 96-well sterile tissue culture plate in a total volume of $100 \mu \mathrm{L}, 5 \mu \mathrm{L}$ cell lysate was added to $20 \mu \mathrm{M}$ Z-DEVD-aLuc in $1 \mathrm{X}$ Assay Buffer in one 
well. Blanc samples contained no cell lysate. We incubated the 96 -well plate at $37^{\circ} \mathrm{C}$ for $1 \mathrm{~h}$. The $50 \mu \mathrm{L}$ of samples were mixed with $50 \mu \mathrm{L}$ of Luciferase Detection Reagent (Promega, USA) in a new black wall 96-well microtiter plate. Luminescence was measured by multimode microplate reader (Victor 1430, Wallac, Perkin Elmer) recording counts per seconds (cps). Blanc data were subtracted from all values. Each sample was assayed in triplicates.

\subsection{LDH Assay}

Cells were plated $\left(2 \times 10^{5}\right)$ in $500 \mu \mathrm{L}$ media in 24-well tissue culture plates and treated as indicated on the graphs. After $72 \mathrm{~h}$ cells and supernatants were centrifuged down $\left(3000 \mathrm{rpm}, 5 \mathrm{~min}\right.$, at $\left.4{ }^{\circ} \mathrm{C}\right)$. The $50 \mu \mathrm{L}$ supernatant was measured to one well of the 96-well sterile microtiter plate and the LDH reaction mixture was added (Catalyst solution and Dye solution in 1:45 ratio) in $50 \mu \mathrm{L}$ according to the instructions of the manufacturer (Roche, Basel, Switzerland). Blanc wells contained media instead of supernatant. After $10 \mathrm{~min}$ incubation at RT we measured absorbance at $490 \mathrm{~nm}$ by multimode microplate reader (Victor 1430, Wallac, Perkin Elmer). Blanc data were subtracted from all values. Each sample was assayed in triplicates.

\subsection{Quantitative Real-Time PCR ( $q R T-P C R)$}

HL-60 cells $\left(1 \times 10^{6}\right)$ were treated with DU325 in 6-well plates (Corning) in $2 \mathrm{~mL}$ in triplicate at $37^{\circ} \mathrm{C}$ for $6,12,24$, and $48 \mathrm{~h}$. Cells were harvested by centrifugation. RNA was purified as described previously [21]. The nucleic acid preparation was done by using the RNA purification kit (Direct-zol ${ }^{\mathrm{TM}}$ RNA MiniPrep Kit, Zymo Research, Irvine, CA, USA), following the instructions of the manufacturer. The quality and quantity of the isolated RNA were measured with NanoDrop1000 v. 3.8.1. (Thermo Fisher Scientific, Waltham, MA, USA). Reverse transcription from $3 \mu \mathrm{g}$ of total RNA was performed with the High-Capacity cDNA Archive Kit (Applied Biosystems, Foster, CA, USA) in a total volume of $30 \mu \mathrm{L}$ according to the manufacturer's protocol. After dilution with $130 \mu \mathrm{L}$ of ultrapure water (Applied Biosystems), cDNA was used as template for gene expression analysis. Quantitative real-time PCR (qRT-PCR) was performed on the LightCycler ${ }^{\circledR} 96$ System (Roche), using gene-specific primers with SYBR Green protocol, as described previously [83]. Briefly, for cycling, each $10 \mu \mathrm{L}$ PCR reaction contained $1 \mu \mathrm{L}$ cDNA (18.75 ng), $250 \mathrm{nM}$ primers, and $5 \mu \mathrm{L}$ qPCRBIO SyGreen Mix Lo-ROX (2x, PCR Biosystems, London, UK). Primer sequences and accession numbers used in the study are listed in the Table 1. The PCR protocol was as follows; enzyme activation at $95{ }^{\circ} \mathrm{C}$ for $2 \mathrm{~min}, 45$ cycles of denaturation at $95^{\circ} \mathrm{C}$ for $10 \mathrm{~s}$, annealing at $60^{\circ} \mathrm{C}$, and extension at $60^{\circ} \mathrm{C}$ for $10 \mathrm{~s}$. All the PCRs were performed with three replicates. After amplification, the melting curve was checked to verify the specificity of the PCR reactions. The $\mathrm{Ct}$ (cycle threshold) values were normalized to ACTB gene for each time point. The presented relative gene expression ratios were calculated using the comparative $\mathrm{Ct}$ method $\left(2^{-\Delta \Delta C T}\right)$. Fold change refers to $2^{-\Delta \Delta C T}$ treated $/ 2^{-\Delta \Delta C T}$ untreated. All values were presented as mean \pm standard deviation (SD). 
Table 1. List of the primers used in the study.

\begin{tabular}{ccccc}
\hline Protein Product & $\begin{array}{c}\text { Gene } \\
\text { Symbol }\end{array}$ & $\begin{array}{c}\text { Accession } \\
\text { Number }\end{array}$ & Forward Primer & Reverse Primer \\
\hline $\begin{array}{c}\text { Myeloid Cell } \\
\text { Surface Antigen } \\
\text { CD33 }\end{array}$ & CD33 & $\begin{array}{c}\text { NM_001082618.1 } \\
\text { NM_001177608.1 }\end{array}$ & ctgacctgctctgtgtcctg & atgagcaccgaggagtgagt \\
\hline $\begin{array}{c}\text { Jun } \\
\text { Proto-Oncogene }\end{array}$ & JUN & NM_002228.3 & ccaaaggatagtgcgatgttt & ctgtcctctccactgcaac \\
\hline $\begin{array}{c}\text { Fos } \\
\text { Proto-Oncogene }\end{array}$ & FOS & NM_005252.3 & actaccactcaccegcagac & ccaggtccgtgcagaagt \\
\hline $\begin{array}{c}\text { JunB } \\
\text { Proto-Oncogene }\end{array}$ & JUNB & NM_002229.2 & atacacagctacgggatacgg & gctcggtttcaggagtttgt \\
\hline $\begin{array}{c}\text { JunD } \\
\text { Proto-Oncogene }\end{array}$ & JUND & NM_005354.5 & cagcgaggagcaggagtt & gagctggttctgcttgtgtaaat \\
\hline Actin Beta & ACTB & BC002409.2 & attggcaatgagcggttc & cgtggatgccacaggact \\
\hline
\end{tabular}

\subsection{Purification of Nuclei and Immunochemical Analysis}

Purification of nuclei from HL-60 cells was performed following a previously reported procedure [48]. For Western blot analysis, total lysates from cells and nuclei were separated on $7.5 \%$ polyacrylamide denaturing gels and blotted to nitrocellulose membranes (GE Healthcare Life Science, Little Chalfont, UK). The membranes were then reacted with antibodies directed against Vav1, p174-Vav1, and Lamin B (Santa Cruz Biotechnology, Santa Cruz, CA, USA) and against $\beta$-tubulin (Sigma-Aldrich, St. Louis, MO, USA), incubated with peroxidase-conjugated secondary antibodies and revealed using the ECL system (PerkinElmer, Boston, MA, USA), as previously reported [84]. The chemiluminescence-derived bands were acquired with ImageQuant ${ }^{\mathrm{TM}}$ LAS 4000 biomolecular imager (GE Healthcare), and the densitometrical analysis was performed by means of Image Quant TL software (GE Healthcare), the ratio of phosphorylated Vav (pVav) to Vav1 was quantitated.

\subsection{Measurement of the MPO Activity}

Cells were treated $\left(1 \times 10^{6} \mathrm{HL}-60\right.$ cells in $1 \mathrm{~mL}$ media) in 24-well tissue culture plates for $48 \mathrm{~h}$ in the concentrations indicated in the graphs. After $48 \mathrm{~h}$ cells and supernatants were harvested and centrifuged down $\left(3000 \times g, 5 \mathrm{~min}, 4^{\circ} \mathrm{C}\right.$, Eppendorf). After the withdrawal of the supernatant, the pellet was fresh-frozen in liquid nitrogen. Samples were freeze-thawed in liquid nitrogen three times, and then centrifuged. A $12 \mu \mathrm{L}$ aliquot of the supernatant was mixed with $280 \mu \mathrm{L}$ of phosphate buffer (50 mM, pH 6) containing $0.167 \mathrm{mg} / \mathrm{mL}$ of O-dianisidine dihydrochloride and the reaction was started with $10 \mu \mathrm{L}$ of $0.03 \%$ hydrogen peroxide and assayed spectrophotometrically at $490 \mathrm{~nm}$ (Benchmark Microplate Reader; Bio-Rad, Budapest, Hungary) after $90 \mathrm{~s}$ of shaking [85]. The MPO activity of the samples $(\mathrm{U} / \mathrm{mL})$ was normalized to the protein content of each sample. Protein concentration $(\mathrm{C})$ was calculated according to the following equation, $C$ protein $(\mathrm{mg} / \mathrm{mL})=(1.55 \times \mathrm{A} 280)-(0.76 \times \mathrm{A} 260) \times$ $\mathrm{D}$, where D means the dilution of the lysate. The normalized MPO activity $(\mathrm{U} / \mathrm{mg})$ was calculated according to the following equation, enzyme activity $(\mathrm{U} / \mathrm{mL}) /$ protein concentration $(\mathrm{mg} / \mathrm{mL})$.

\subsection{Fluorescence Flow Cytometry}

\subsubsection{Detection of the Mitochondrial Membrane Potential (MMP)}

Cells $(200,000)$ were plated in 24-well tissue culture plates (Corning Life Sciences) and treated with the indicated concentrations in the figures in $500 \mu \mathrm{L}$ RPMI-1640 media with 10\% FCS for 4 and $24 \mathrm{~h}$. Mitochondrial membrane potential was measured as described previously in reference [21]. After 4 and $24 \mathrm{~h}$, the cells were harvested and centrifuged (2000 rpm, $5 \mathrm{~min})$. The pellet was suspended and incubated for $15 \mathrm{~min}$ in $5 \mu \mathrm{g} / \mathrm{mL} \mathrm{JC}-1$ (5, $5^{\prime}, 6,6^{\prime}$-tetrachloro-1,1', 3, $3^{\prime}$-tetraethyl-imidacarbocyanine iodide, 
Chemodex, St. Gallen, Switzerland) in final volume $300 \mu \mathrm{L}$ of cell culture media at $37^{\circ} \mathrm{C}$. Cells $\left(2 \times 10^{4}\right)$ were acquired immediately on a FACSCalibur flow cytometer. Cells were visualized using FL2 (cells with steady state mitochondria) $(585 / 42 \mathrm{~nm}$ ) and FL1 (cells with depolarized mitochondria) $(530 / 30 \mathrm{~nm})$ channels. Data were analyzed using CellQuestTM software (CellQuest Pro v5.1, Becton Dickinson, Franklin Lakes, NJ, USA). Bar graphs showed the percentage of FL1 positive cells visualized by GraphPad Prism ${ }^{\circledR} 5$.

\subsubsection{Detection of Phosphatidylserine Exposure}

Cells $(200,000)$ were plated in 24-well tissue culture plates (Corning Life Sciences) and treated with the indicated concentrations in the figures in $500 \mu \mathrm{L}$ RPMI-1640 media with $10 \%$ FCS. After $48 \mathrm{~h}$ incubation for the AML1 cells and $72 \mathrm{~h}$ for the murine splenocytes, the supernatants were harvested. Cells were harvested with the corresponding supernatant and centrifuged down (2000 rpm, $5 \mathrm{~min}$, Eppendorf). The pellet was resuspended in Annexin V binding buffer $(0.01 \mathrm{M} \mathrm{HEPES}, 0.14 \mathrm{M} \mathrm{NaCl}$ and $2.5 \mathrm{mM} \mathrm{CaCl}_{2}$ ). Annexin V-Alexa Fluor ${ }^{\circledR} 488$ (Life Technologies, 2.5:100) was added to the cells, which were then kept for $15 \mathrm{~min}$ in the dark at room temperature. Before the acquisition, propidium iodide (10 $\mu \mathrm{g} / \mathrm{mL}$, Sigma-Aldrich) was added in Annexin V binding buffer to dilute Annexin V-Alexa Fluor ${ }^{\circledR} 4885$ X. Cells (20,000 events) were analyzed on a FACSCalibur flow cytometer using CellQuest ${ }^{\mathrm{TM}}$ software (Becton Dickinson). The percentage of the FL1 (530/30 nm filter, Annexin V-Alexa Fluor ${ }^{\circledR} 488$ ) positive and FL3 (670 nm filter, propidium iodide) negative early apoptotic cells and FL1 positive and FL3 positive late apoptotic cells were determined. The total apoptotic population includes both early and late apoptotic cells. Column charts were created by GraphPad Prism ${ }^{\circledR} 5$.

\subsubsection{Cell Cycle and Sub-G1 Analysis}

Cells $(200,000)$ were plated in 24-well tissue culture plates (Corning Life Sciences) in RPMI-1640 $10 \%$ FCS (Gibco) and were treated with the indicated concentrations in the figures in $500 \mu \mathrm{L}$ media. After $72 \mathrm{~h}$ the supernatant was harvested. Cells were harvested with the corresponding supernatant and centrifuged down (2000 rpm, $5 \mathrm{~min}$, Eppendorf). Pellet was resuspended in DNA binding buffer ( $1 \times$ PBS, $0.1 \%$ tri-sodium-citrate, $10 \mu \mathrm{g} / \mathrm{mL}$ PI, $0.1 \%$ Triton X-100, $10 \mu \mathrm{g} / \mathrm{mL}$ RNase A, (Sigma-Aldrich)). After 30 min incubation at room temperature, cells (20,000 events) were acquired on a FACSCalibur flow cytometer (Becton Dickinson), and the sub-G1 apoptotic population was analyzed on FL3 histograms using CellQuest ${ }^{\mathrm{TM}}$ software (Becton Dickinson) gating out debris. We gated out doublets for cell cycle analysis which was based on FL2-A/FL2-W dot plots, using ModFit software (v. 2.0, Becton Dickinson). Column charts were created by GraphPad Prism ${ }^{\circledR} 5$.

\subsubsection{Immunofluorescence}

Cells $(500,000)$ were plated in 24-well tissue culture plates (Corning Life Sciences) in RPMI-1640 $10 \%$ FCS (Gibco) and were treated with the indicated concentrations in the figures in $500 \mu \mathrm{L}$ media. After the incubation time presented in the graph or in the text, supernatant was harvested. Cells were harvested with the corresponding supernatant and centrifuged down (2000 rpm, 5 min, Eppendorf). The antibodies used for flow cytometry are listed in Table 2. Pellet was resuspended and fixed either in $3.5 \%$ PBS buffered formaldehyde (Molar Chemicals) for $10 \mathrm{~min}$ or resuspended in FACs-buffer ( $2 \%$ FCS, (Gibco) in PBS) for native staining. Cells were washed with FACS-buffer, centrifuged down (2000 rpm, 5 min, Eppendorf). In order to detect pERK, Bcl-xl, pAkt, and active caspase-3, separately, the cells were permeabilized in Permeability buffer ( $1 \%$ FCS, $0.1 \%$ saponin (Sigma-Aldrich) in PBS pH 7.4) for $5 \mathrm{~min}$. The detection of CD11b, CD33, CD45, Ly6C, and Ly5G was performed by native cell surface staining gated on PI negative living cells. Cells were washed with FACS buffer, centrifuged down (2000 rpm, $5 \mathrm{~min}$, Eppendorf). After incubation for $1 \mathrm{~h}$ at $4{ }^{\circ} \mathrm{C}$ with the antibody(s) samples were washed two times with FACS buffer. The secondary antibody detecting caspase-3, anti-rabbit IgG conjugated with Alexa Fluor ${ }^{\circledR} 488$ (Thermo Fisher Scientific) was diluted to 1:600 and incubated with the cells for $30 \mathrm{~min}$ at $4{ }^{\circ} \mathrm{C}$. After washing, $300 \mu \mathrm{L}$ FACS buffer was added for acquisition with the 
FACSCalibur flow cytometer and CellQuest ${ }^{\mathrm{TM}}$ software (Becton Dickinson) acquiring 20,000 events. The percentage of the positive cells is demonstrated in the graphs. Column charts were created by GraphPad Prism ${ }^{\circledR} 5$.

Table 2. List of the antibodies used for flow cytometry.

\begin{tabular}{|c|c|c|c|c|}
\hline Target & Host/Clone & Fluorochrome & $\begin{array}{l}\text { Supplier, Cat. } \\
\text { Number }\end{array}$ & $\begin{array}{c}\text { Dilution in the } \\
\text { Assay }\end{array}$ \\
\hline $\begin{array}{c}\text { pERK1/2 } \\
\text { (Thr202/Tyr204) }\end{array}$ & $\begin{array}{l}\text { Mouse mAb, } \\
\text { 4B11B69 }\end{array}$ & Alexa Fluor ${ }^{\circledR} 488$ & Biolegend, 675508 & $1: 25$ \\
\hline Bcl-xl & Rabbit mAb, 54H6 & Alexa Fluor ${ }^{\circledR} 488$ & $\begin{array}{c}\text { Cell Sign. Techn. } \\
2767\end{array}$ & $1: 75$ \\
\hline pAkt (Ser473) & Rabbit mAb, D9E & Alexa Fluor ${ }^{\circledR} 488$ & $\begin{array}{l}\text { Cell Sign. Techn. } \\
4071\end{array}$ & $1: 50$ \\
\hline Caspase-3 (Asp175) & Rabbit polyclonal & none & $\begin{array}{l}\text { Cell Sign. Techn. } \\
9661\end{array}$ & $1: 500$ \\
\hline Anti-rabbit $(\mathrm{H}+\mathrm{L})$ & Goat polyclonal & Alexa Fluor ${ }^{\circledR} 488$ & $\begin{array}{l}\text { Thermo Fisher Sci. } \\
\text { A-11008 }\end{array}$ & $1: 600$ \\
\hline CD11b & Mouse mAb, LT11 & FITC & $\begin{array}{c}\text { ImmunoTools, } \\
21389113\end{array}$ & $1: 20$ \\
\hline CD33 & $\begin{array}{l}\text { Mouse mAb, } \\
\text { WM53 }\end{array}$ & PE-Cy5.5 & $\begin{array}{l}\text { Thermo Fisher Sci. } \\
\text { A15454 }\end{array}$ & 1:00 \\
\hline CD45 & $\begin{array}{l}\text { Mouse mAb, } \\
\text { 30-F11 }\end{array}$ & FITC & Biolegend, 103107 & $1: 200$ \\
\hline CD11b & Rat mAb, M1/70 & $\mathrm{PE}$ & Biolegend, 101208 & $1: 80$ \\
\hline Ly6C & Rat mAb, HK1.4 & APC & Biolegend, 128016 & $1: 80$ \\
\hline Ly6G & Rat $\mathrm{mAb}, 1 \mathrm{~A} 8$ & APC & Biolegend, 127614 & $1: 330$ \\
\hline
\end{tabular}

\subsection{Mass Cytometry}

Mass cytometry was performed as described previously with minor modifications $[29,86]$. Briefly, $1.5 \times 10^{6}$ cells were plated in six-well plates for the treatment by $40 \mathrm{nM}$ or $200 \mathrm{nM}$ DU325 or left untreated (untr.) in $2 \mathrm{~mL}$ RPMI 10\% FCS media for $48 \mathrm{~h}$. After the incubation time, three biological replicates were harvested, pooled, and processed for mass cytometry staining. Cells were centrifuged at $400 \times g$ for $5 \mathrm{~min}$ and assayed for viability by cisplatin staining $\left(5 \mu \mathrm{M}^{195} \mathrm{Pt}\right.$, Fluidigm San Francisco, CA, USA) for 3 min on ice in $300 \mu \mathrm{L}$ PBS. Samples were diluted by $1000 \mu \mathrm{L}$ Maxpar Cell Staining Buffer (MCSB, 201068, Fluidigm) and centrifuged at $400 \times g$ for $5 \mathrm{~min}$. The pellet was resuspended in $50 \mu \mathrm{L}$ MCSB and the antibody mix (Table 3) was added in $50 \mu \mathrm{L}$ at 100X final dilution. The Maxpar ${ }^{\circledR}$ Human Monocyte/Macrophage Phenotyping Panel Kit (201317, Fluidigm,) was used for mass cytometric analysis (Table 3). After $45 \mathrm{~min}$ incubation at $4{ }^{\circ} \mathrm{C}$, antibodies were washed two times by $1 \mathrm{~mL}$ MCSB and centrifuged at $400 \times g$ for $5 \mathrm{~min}$. The cells were suspended in the residual volume and fixed in $1.6 \%$ formaldehyde (freshly diluted from $16 \%$ Pierce formaldehyde with PBS, Thermo Fisher Scientific) and incubated for $10 \mathrm{~min}$ at $4{ }^{\circ} \mathrm{C}$. Cells were centrifuged at $800 \times g$ for $5 \mathrm{~min}$. The DNA intercalator (201192A, Cell ID 191/193 Iridium, Fluidigm) was added in 125 nM in Maxpar Fix and Perm (201067, Fluidigm) in $350 \mu \mathrm{L}$ for overnight at $4{ }^{\circ} \mathrm{C}$. Next day, the cells for the acquisition were centrifuged at $800 \times g$ for $5 \mathrm{~min}$ then were washed by $2 \mathrm{~mL}$ MCSB and centrifuged at $800 \times g$ for $5 \mathrm{~min}$. Cells were suspended in $1 \mathrm{~mL}$ PBS (for WB injector, 107950, Fluidigm) and counted in a Bürker chamber during centrifugation. For acquisition, the concentration of cells was set to $0.5 \times 10^{6} / \mathrm{mL}$ in cell acquisition solution (CAS, 201241, Fluidigm) containing 10\% EQ Calibration Beads (201078, Fluidigm). Cells were filtered through $30 \mu \mathrm{m}$ gravity filter (CellTrics, Sysmex Gmbh, Bornbach, Germany) and acquired freshly. Mass cytometry data were analyzed in Cytobank (Beckman Coulter, Brea, CA, USA). 
Viable cells and single cells were determined, viSNE (visualization of stochastic neighbor embedding) analysis (iterations $=1000$, perplexity $=30$, theta $=0.5$ ), was carried out on $5 \times 10^{4}$ single cell events.

Table 3. List of the antibodies used for mass cytometry.

\begin{tabular}{ccc}
\hline Target & Clone & Metal Tag \\
\hline CD19 & HIB19 & $142 \mathrm{Nd}$ \\
\hline CD11b & ICRF44 & $144 \mathrm{Nd}$ \\
\hline CD7 & CD7-6B7 & $147 \mathrm{Sm}$ \\
\hline CD66 & CD66a-B1.1 & $149 \mathrm{Sm}$ \\
\hline CD36 & $5-271$ & $152 \mathrm{Sm}$ \\
\hline CD163 & GHI/61 & $154 \mathrm{Sm}$ \\
\hline CD45 & HI30 & $156 \mathrm{Gd}$ \\
\hline CD11c & Bu15 & $159 \mathrm{~Tb}$ \\
\hline CD14 & M5E2 & $160 \mathrm{Gd}$ \\
\hline CD16 & $3 \mathrm{G} 8$ & $165 \mathrm{Ho}$ \\
\hline CD38 & HIT2 & $167 \mathrm{Er}$ \\
\hline CD206 & $15-2$ & $168 \mathrm{Er}$ \\
\hline CD33 & WM53 & $169 \mathrm{Tm}$ \\
\hline CD3 & UCHT1 & $170 \mathrm{Er}$ \\
\hline HLA-DR & L243 & $174 \mathrm{Yb}$ \\
\hline
\end{tabular}

\subsection{Statistical Analysis}

Statistical analysis was performed using two-tailed, homoscedastic Student's t-test to evaluate the statistical significance (set at ${ }^{*} p<0.05,{ }^{* *} p<0.01,{ }^{* * *} p<0.001$ ) between two given experimental groups: pairwise comparison of each sample to the untreated control.

\section{Conclusions}

The imidazo[1,2-b]pyrazole-7-carboxamide derivative, DU325 drug candidate induces differentiation-coupled apoptosis of immature myeloid cells such as HL-60 and human patient-derived AML cells. The sensitivity of myeloid-derived suppressor cells to DU325 was shown using MDSCs from the murine $4 \mathrm{~T} 1$ breast cancer model. Pathways, such as ERK1/2 phosphorylation, Bcl-xl induction and Akt phosphorylation, accumulation of Vav1, induction of AP-1 TF complex are involved in the response to DU325 of HL-60 cells. Maturation of HL-60 cells led to apoptotic cell death, the depolarization of mitochondria, activation of caspase-3, and degradation of DNA. The subpopulations of CD7+, CD33+, $\mathrm{CD} 7+/ \mathrm{CD} 33+, \mathrm{CD} 206+$, and CD38 ${ }^{\text {bright }}$ were the most sensitive to DU325 treatment of human primary AML cells.

\section{Patents}

The imidazo-pyrazole carboxamide derivative of the study has been patented entitled "Imidazo-pyrazole carboxamide derivatives as anticancer agents and the synthesis thereof", WO2019220155.

Supplementary Materials: Supplementary materials can be found at http://www.mdpi.com/1422-0067/21/14/ 5135/s1. The followings are available online. Figure S1: DU325 drives survival pathways, increases pERK, $\mathrm{Bcl}-\mathrm{xl}$, and pAkt bright cells, as an early response to treatment, Figure S2: Representative Western blots show the accumulation of Vav1 in whole cell lysates (A) and in isolated nuclei (B) upon treatment, Figure S3: DU325 induces the differentiation, increases the granularity and CD11b expression of HL-60 promyeloblasts, Figure S4: DU325 induces the depolarization of the mitochondrial membrane potential (MMP), Figure S5: DU325 treatment increased the percentage of cleaved caspase-3 positive cells, Figure S6: DU325 treatment 
increased the percentage of the hypo-diploid apoptotic cells in the sub-G1 population, Figure S7: DU325 hampers the viability of human patient-derived bone marrow aspirate AML cells, Figure S8: Mass cytometric gating strategy of the immunophenotyping of the human patient-derived bone marrow aspirate AML cells upon treatment by DU325, Figure S9: The multiparametric tSNE analysis of human patient-derived AML bone marrow aspirate cells treated by DU325, Figure S10: The CD11b+/Ly6C+ monocytic myeloid-derived suppressor cells are sensitive to DU325 treatment, Figure S11: The CD11b+/Ly6G+ granulocytic myeloid-derived suppressor cells are sensitive to DU325 treatment.

Author Contributions: Conceptualization, L.G.P. and G.J.S.; methodology, E.K., J.Á.B., L.I.N., R.A., V.B., F.B., A.D., A.K.K., P.B., G.M., R.S., I.K., and G.J.S.; software, E.K., J.Á.B., and G.J.S.; validation, E.K. and G.J.S.; formal analysis, E.K. and G.J.S.; investigation, E.K., J.Á.B., L.I.N., R.A., V.B., F.B., A.D., A.K.K., P.B., G.M., R.S., I.K., C.V., and G.J.S; resources, L.G.P.; data curation, E.K., J.Á.B., C.V., L.G.P., and G.J.S.; writing-original draft preparation, G.J.S.; writing—review and editing, V.B., P.B., L.G.P., and G.J.S.; visualization, E.K., J.Á.B., and G.J.S.; supervision, L.G.P. and G.J.S., project administration, L.G.P. All authors have read and agreed to the published version of the manuscript.

Funding: This research was funded by the following grants, GINOP-2.3.2-15-2016-00001 and GINOP-2.3.2-15-2016-00030 by the National Research, Development and Innovation Office, Hungary; Gábor J. Szebeni was supported by János Bolyai Research Scholarship of the Hungarian Academy of Sciences (BO/00139/17/8) and by the UNKP-19-4-SZTE-36 New National Excellence Program of the Ministry for Innovation and Technology.

Conflicts of Interest: Laszló G. Puskás is the owner of Avidin Ltd. Róbert Alföldi is the CEO of AstridBio Technologies Ltd. The authors declare no conflicts of interest.

\section{References}

1. Vardiman, J.W.; Thiele, J.; Arber, D.A.; Brunning, R.D.; Borowitz, M.J.; Porwit, A.; Harris, N.L.; Le Beau, M.M.; Hellstrom-Lindberg, E.; Tefferi, A.; et al. The 2008 revision of the World Health Organization (WHO) classification of myeloid neoplasms and acute leukemia: Rationale and important changes. Blood 2009, 114, 937-951. [CrossRef] [PubMed]

2. Germing, U.; Kobbe, G.; Haas, R.; Gattermann, N. Myelodysplastic syndromes: Diagnosis, prognosis, and treatment. Dtsch. Arztebl. Int. 2013, 110, 783-790. [CrossRef] [PubMed]

3. Shallis, R.M.; Wang, R.; Davidoff, A.; Ma, X.M.; Zeidan, A.M. Epidemiology of acute myeloid leukemia: Recent progress and enduring challenges. Blood Rev. 2019, 36, 70-87. [CrossRef]

4. DiNardo, C.D.; Garcia-Manero, G.; Pierce, S.; Nazha, A.; Bueso-Ramos, C.; Jabbour, E.; Ravandi, F.; Cortes, J.; Kantarjian, H. Interactions and relevance of blast percentage and treatment strategy among younger and older patients with acute myeloid leukemia (AML) and myelodysplastic syndrome (MDS). Am. J. Hematol. 2016, 91, 227-232. [CrossRef] [PubMed]

5. Tefferi, A.; Pardanani, A. Myeloproliferative Neoplasms: A Contemporary Review. JAMA Oncol. 2015, 1, 97-105. [CrossRef]

6. Moen, M.D.; McKeage, K.; Plosker, G.L.; Siddiqui, M.A. Imatinib: A review of its use in chronic myeloid leukaemia. Drugs 2007, 67, 299-320. [CrossRef]

7. Gangat, N.; Patnaik, M.M.; Tefferi, A. Myelodysplastic syndromes: Contemporary review and how we treat. Am. J. Hematol. 2016, 91, 76-89. [CrossRef]

8. Watts, J.; Nimer, S. Recent advances in the understanding and treatment of acute myeloid leukemia. F1000Res 2018, 7. [CrossRef]

9. De Kouchkovsky, I.; Abdul-Hay, M. 'Acute myeloid leukemia: A comprehensive review and 2016 update'. Blood Cancer J. 2016, 6, e441. [CrossRef]

10. Jimenez, J.J.; Chale, R.S.; Abad, A.C.; Schally, A.V. Acute promyelocytic leukemia (APL): A review of the literature. Oncotarget 2020, 11, 992-1003. [CrossRef]

11. Birnie, G.D. The HL60 cell line: A model system for studying human myeloid cell differentiation. Br. J. Cancer Suppl. 1988, 9, 41-45. [PubMed]

12. Mark Welch, D.B.; Jauch, A.; Langowski, J.; Olins, A.L.; Olins, D.E. Transcriptomes reflect the phenotypes of undifferentiated, granulocyte and macrophage forms of HL-60/S4 cells. Nucleus 2017, 8, 222-237. [CrossRef] [PubMed]

13. Collins, S.J.; Gallo, R.C.; Gallagher, R.E. Continuous growth and differentiation of human myeloid leukaemic cells in suspension culture. Nature 1977, 270, 347-349. [CrossRef] [PubMed] 
14. Collins, S.J.; Robertson, K.A.; Mueller, L. Retinoic acid-induced granulocytic differentiation of HL-60 myeloid leukemia cells is mediated directly through the retinoic acid receptor (RAR-alpha). Mol. Cell. Biol. 1990, 10, 2154-2163. [CrossRef] [PubMed]

15. Collins, S.J.; Ruscetti, F.W.; Gallagher, R.E.; Gallo, R.C. Terminal differentiation of human promyelocytic leukemia cells induced by dimethyl sulfoxide and other polar compounds. Proc. Natl. Acad. Sci. USA 1978, 75, 2458-2462. [CrossRef] [PubMed]

16. Rovera, G.; Santoli, D.; Damsky, C. Human promyelocytic leukemia cells in culture differentiate into macrophage-like cells when treated with a phorbol diester. Proc. Natl Acad. Sci. USA 1979, 76, 2779-2783. [CrossRef]

17. Mangelsdorf, D.J.; Koeffler, H.P.; Donaldson, C.A.; Pike, J.W.; Haussler, M.R. 1,25-Dihydroxyvitamin D3-induced differentiation in a human promyelocytic leukemia cell line (HL-60): Receptor-mediated maturation to macrophage-like cells. J. Cell Biol. 1984, 98, 391-398. [CrossRef]

18. Petrie, K.; Zelent, A.; Waxman, S. Differentiation therapy of acute myeloid leukemia: Past, present and future. Curr. Opin. Hematol. 2009, 16, 84-91. [CrossRef]

19. De The, H. Differentiation therapy revisited. Nat. Rev. Cancer 2018, 18, 117-127. [CrossRef]

20. Demjen, A.; Alfoldi, R.; Angyal, A.; Gyuris, M.; Hackler, L., Jr.; Szebeni, G.J.; Wolfling, J.; Puskas, L.G.; Kanizsai, I. Synthesis, cytotoxic characterization, and SAR study of imidazo[1,2-b]pyrazole-7-carboxamides. Arch. Pharm. (Weinh.) 2018, 351, e1800062. [CrossRef]

21. Szebeni, G.J.; Balog, J.A.; Demjen, A.; Alfoldi, R.; Vegi, V.L.; Feher, L.Z.; Man, I.; Kotogany, E.; Guban, B.; Batar, P.; et al. Imidazo[1,2-b]pyrazole-7-carboxamides Induce Apoptosis in Human Leukemia Cells at Nanomolar Concentrations. Molecules 2018, 23. [CrossRef] [PubMed]

22. Strauss, L.; Sangaletti, S.; Consonni, F.M.; Szebeni, G.; Morlacchi, S.; Totaro, M.G.; Porta, C.; Anselmo, A.; Tartari, S.; Doni, A.; et al. RORC1 Regulates Tumor-Promoting "Emergency" Granulo-Monocytopoiesis. Cancer Cell 2015, 28, 253-269. [CrossRef] [PubMed]

23. Szebeni, G.J.; Vizler, C.; Kitajka, K.; Puskas, L.G. Inflammation and Cancer: Extra- and Intracellular Determinants of Tumor-Associated Macrophages as Tumor Promoters. Mediat. Inflamm. 2017, 2017, 9294018. [CrossRef] [PubMed]

24. Kumar, V.; Patel, S.; Tcyganov, E.; Gabrilovich, D.I. The Nature of Myeloid-Derived Suppressor Cells in the Tumor Microenvironment. Trends Immunol. 2016, 37, 208-220. [CrossRef] [PubMed]

25. Gabrilovich, D.I.; Ostrand-Rosenberg, S.; Bronte, V. Coordinated regulation of myeloid cells by tumours. Nat. Rev. Immunol. 2012, 12, 253-268. [CrossRef] [PubMed]

26. Katoh, H.; Watanabe, M. Myeloid-Derived Suppressor Cells and Therapeutic Strategies in Cancer. Mediat. Inflamm. 2015, 2015, 159269. [CrossRef]

27. Shipp, C.; Speigl, L.; Janssen, N.; Martens, A.; Pawelec, G. A clinical and biological perspective of human myeloid-derived suppressor cells in cancer. Cell. Mol. Life Sci. 2016, 73, 4043-4061. [CrossRef]

28. Szebeni, G.J.; Vizler, C.; Nagy, L.I.; Kitajka, K.; Puskas, L.G. Pro-Tumoral Inflammatory Myeloid Cells as Emerging Therapeutic Targets. Int. J. Mol. Sci. 2016, 17, 1958. [CrossRef]

29. Balog, J.A.; Hackler, L., Jr.; Kovacs, A.K.; Neuperger, P.; Alfoldi, R.; Nagy, L.I.; Puskas, L.G.; Szebeni, G.J. Single Cell Mass Cytometry Revealed the Immunomodulatory Effect of Cisplatin Via Downregulation of Splenic CD44+, IL-17A+ MDSCs and Promotion of Circulating IFN-gamma+ Myeloid Cells in the 4T1 Metastatic Breast Cancer Model. Int. J. Mol. Sci. 2019, 21, 170. [CrossRef]

30. Wesolowski, R.; Markowitz, J.; Carson, W.E., 3rd. Myeloid derived suppressor cells—a new therapeutic target in the treatment of cancer. J. Immunother. Cancer 2013, 1, 10. [CrossRef]

31. Law, A.M.K.; Valdes-Mora, F.; Gallego-Ortega, D. Myeloid-Derived Suppressor Cells as a Therapeutic Target for Cancer. Cells 2020, 9, 561. [CrossRef]

32. Testa, U.; Masciulli, R.; Tritarelli, E.; Pustorino, R.; Mariani, G.; Martucci, R.; Barberi, T.; Camagna, A.; Valtieri, M.; Peschle, C. Transforming growth factor-beta potentiates vitamin D3-induced terminal monocytic differentiation of human leukemic cell lines. J. Immunol. 1993, 150, 2418-2430. [PubMed]

33. Young, M.R.; Ihm, J.; Lozano, Y.; Wright, M.A.; Prechel, M.M. Treating tumor-bearing mice with vitamin D3 diminishes tumor-induced myelopoiesis and associated immunosuppression, and reduces tumor metastasis and recurrence. Cancer Immunol Immunother. 1995, 41, 37-45. [CrossRef] [PubMed] 
34. Mirza, N.; Fishman, M.; Fricke, I.; Dunn, M.; Neuger, A.M.; Frost, T.J.; Lush, R.M.; Antonia, S.; Gabrilovich, D.I. All-trans-retinoic acid improves differentiation of myeloid cells and immune response in cancer patients. Cancer Res. 2006, 66, 9299-9307. [CrossRef] [PubMed]

35. Lee, M.; Park, C.S.; Lee, Y.R.; Im, S.A.; Song, S.; Lee, C.K. Resiquimod, a TLR7/8 agonist, promotes differentiation of myeloid-derived suppressor cells into macrophages and dendritic cells. Arch. Pharm. Res. 2014, 37, 1234-1240. [CrossRef]

36. Tasseff, R.; Jensen, H.A.; Congleton, J.; Dai, D.; Rogers, K.V.; Sagar, A.; Bunaciu, R.P.; Yen, A.; Varner, J.D. An Effective Model of the Retinoic Acid Induced HL-60 Differentiation Program. Sci. Rep. 2017, 7, 14327. [CrossRef]

37. Bertagnolo, V.; Brugnoli, F.; Grassilli, S.; Nika, E.; Capitani, S. Vav1 in differentiation of tumoral promyelocytes. Cell Signal. 2012, 24, 612-620. [CrossRef]

38. Huang, Q.; Wang, L.; Ran, Q.; Wang, J.; Wang, C.; He, H.; Li, L.; Qi, H. Notopterol-induced apoptosis and differentiation in human acute myeloid leukemia HL-60 cells. Drug Des. Devel. Ther. 2019, 13, 1927-1940. [CrossRef]

39. Johnson, D.E. Src family kinases and the MEK/ERK pathway in the regulation of myeloid differentiation and myeloid leukemogenesis. Adv. Enzym. Regul. 2008, 48, 98-112. [CrossRef]

40. Moon, D.O.; Asami, Y.; Kim, M.O.; Jang, J.H.; Kim, B.Y.; Ahn, J.S.; Kim, G.Y.; Yun, S.G. Xestospongin C induces monocytic differentiation of HL60 cells through activation of the ERK pathway. Food Chem. Toxicol. 2013, 55, 505-512. [CrossRef]

41. Chatterjee, D.; Han, Z.; Mendoza, J.; Goodglick, L.; Hendrickson, E.A.; Pantazis, P.; Wyche, J.H. Monocytic differentiation of HL-60 promyelocytic leukemia cells correlates with the induction of Bcl-xL. Cell Growth Differ. 1997, 8, 1083-1089. [PubMed]

42. Miranda, M.B.; Dyer, K.F.; Grandis, J.R.; Johnson, D.E. Differential activation of apoptosis regulatory pathways during monocytic vs granulocytic differentiation: A requirement for Bcl-X(L)and XIAP in the prolonged survival of monocytic cells. Leukemia 2003, 17, 390-400. [CrossRef] [PubMed]

43. Busca, A.; Saxena, M.; Iqbal, S.; Angel, J.; Kumar, A. PI3K/Akt regulates survival during differentiation of human macrophages by maintaining NF-kappaB-dependent expression of antiapoptotic Bcl-xL. J. Leukoc. Biol. 2014, 96, 1011-1022. [CrossRef] [PubMed]

44. Bertagnolo, V.; Marchisio, M.; Brugnoli, F.; Bavelloni, A.; Boccafogli, L.; Colamussi, M.L.; Capitani, S. Requirement of tyrosine-phosphorylated Vav for morphological differentiation of all-trans-retinoic acid-treated HL-60 cells. Cell Growth Differ. 2001, 12, 193-200.

45. Bertagnolo, V.; Nika, E.; Brugnoli, F.; Bonora, M.; Grassilli, S.; Pinton, P.; Capitani, S. Vav1 is a crucial molecule in monocytic/macrophagic differentiation of myeloid leukemia-derived cells. Cell Tissue Res. 2011, 345, 163-175. [CrossRef]

46. Houlard, M.; Arudchandran, R.; Regnier-Ricard, F.; Germani, A.; Gisselbrecht, S.; Blank, U.; Rivera, J.; Varin-Blank, N. Vav1 is a component of transcriptionally active complexes. J. Exp. Med. 2002, 195, 1115-1127. [CrossRef]

47. Kuhne, M.R.; Ku, G.; Weiss, A. A guanine nucleotide exchange factor-independent function of Vav1 in transcriptional activation. J. Biol. Chem. 2000, 275, 2185-2190. [CrossRef]

48. Brugnoli, F.; Lambertini, E.; Varin-Blank, N.; Piva, R.; Marchisio, M.; Grassilli, S.; Miscia, S.; Capitani, S.; Bertagnolo, V. Vav1 and PU.1 are recruited to the CD11b promoter in APL-derived promyelocytes: Role of Vav1 in modulating PU.1-containing complexes during ATRA-induced differentiation. Exp. Cell Res. 2010, 316, 38-47. [CrossRef]

49. Mollinedo, F.; Gajate, C.; Tugores, A.; Flores, I.; Naranjo, J.R. Differences in expression of transcription factor AP-1 in human promyelocytic HL-60 cells during differentiation towards macrophages versus granulocytes. Biochem. J. 1993, 294, 137-144. [CrossRef]

50. Hess, J.; Angel, P.; Schorpp-Kistner, M. AP-1 subunits: Quarrel and harmony among siblings. J. Cell Sci. 2004, 117, 5965-5973. [CrossRef]

51. Foletta, V.C.; Segal, D.H.; Cohen, D.R. Transcriptional regulation in the immune system: All roads lead to AP-1. J. Leukoc. Biol. 1998, 63, 139-152. [CrossRef] [PubMed]

52. Karin, M. The regulation of AP-1 activity by mitogen-activated protein kinases. J. Biol. Chem. 1995, 270, 16483-16486. [CrossRef] [PubMed] 
53. Kaminuma, O.; Deckert, M.; Elly, C.; Liu, Y.C.; Altman, A. Vav-Rac1-mediated activation of the c-Jun N-terminal kinase/c-Jun/AP-1 pathway plays a major role in stimulation of the distal NFAT site in the interleukin-2 gene promoter. Mol. Cell. Biol. 2001, 21, 3126-3136. [CrossRef] [PubMed]

54. Schneider, H.; Rudd, C.E. CD28 and Grb-2, relative to Gads or Grap, preferentially co-operate with Vav1 in the activation of NFAT/AP-1 transcription. Biochem Biophys Res. Commun. 2008, 369, 616-621. [CrossRef]

55. Doyle, B.T.; O’Neill, A.J.; Newsholme, P.; Fitzpatrick, J.M.; Watson, R.W. The loss of IAP expression during HL-60 cell differentiation is caspase-independent. J. Leukoc. Biol. 2002, 71, 247-254.

56. Jensen, H.A.; Yourish, H.B.; Bunaciu, R.P.; Varner, J.D.; Yen, A. Induced myelomonocytic differentiation in leukemia cells is accompanied by noncanonical transcription factor expression. FEBS Open Bio 2015, 5, 789-800. [CrossRef]

57. Doyle, B.T.; O’Neill, A.J.; Fitzpatrick, J.M.; Watson, R.W. Differentiation-induced HL-60 cell apoptosis: A mechanism independent of mitochondrial disruption? Apoptosis 2004, 9, 345-352. [CrossRef]

58. Duellman, S.J.; Zhou, W.; Meisenheimer, P.; Vidugiris, G.; Cali, J.J.; Gautam, P.; Wennerberg, K.; Vidugiriene, J. Bioluminescent, Nonlytic, Real-Time Cell Viability Assay and Use in Inhibitor Screening. Assay Drug Dev. Technol. 2015, 13, 456-465. [CrossRef]

59. Kumar, P.; Nagarajan, A.; Uchil, P.D. Analysis of Cell Viability by the Lactate Dehydrogenase Assay. Cold Spring Harb. Protoc. 2018. [CrossRef]

60. Amir el, A.D.; Davis, K.L.; Tadmor, M.D.; Simonds, E.F.; Levine, J.H.; Bendall, S.C.; Shenfeld, D.K.; Krishnaswamy, S.; Nolan, G.P.; Pe'er, D. viSNE enables visualization of high dimensional single-cell data and reveals phenotypic heterogeneity of leukemia. Nat. Biotechnol. 2013, 31, 545-552. [CrossRef]

61. Moschovi, M.; Critselis, E.; Cen, O.; Adamaki, M.; Lambrou, G.I.; Chrousos, G.P.; Vlahopoulos, S. Drugs acting on homeostasis: Challenging cancer cell adaptation. Expert Rev. Anticancer Ther. 2015, 15, 1405-1417. [CrossRef] [PubMed]

62. Winer, E.S.; Stone, R.M. Novel therapy in Acute myeloid leukemia (AML): Moving toward targeted approaches. Ther. Adv. Hematol. 2019, 10, 2040620719860645. [CrossRef]

63. Bertagnolo, V.; Grassilli, S.; Petretto, A.; Lambertini, E.; Astati, L.; Bruschi, M.; Brugnoli, F.; Nika, E.; Candiano, G.; Piva, R.; et al. Nuclear proteome analysis reveals a role of Vav1 in modulating RNA processing during maturation of tumoral promyelocytes. J. Proteom. 2011, 75, 398-409. [CrossRef] [PubMed]

64. Kuranda, K.; Berthon, C.; Lepretre, F.; Polakowska, R.; Jouy, N.; Quesnel, B. Expression of CD34 in hematopoietic cancer cell lines reflects tightly regulated stem/progenitor-like state. J. Cell. Biochem. 2011, 112, 1277-1285. [CrossRef] [PubMed]

65. McCracken, J.M.; Allen, L.A. Regulation of human neutrophil apoptosis and lifespan in health and disease. J. Cell. Death 2014, 7, 15-23. [CrossRef] [PubMed]

66. Kobayashi, S.D.; Voyich, J.M.; Somerville, G.A.; Braughton, K.R.; Malech, H.L.; Musser, J.M.; DeLeo, F.R. An apoptosis-differentiation program in human polymorphonuclear leukocytes facilitates resolution of inflammation. J. Leukoc. Biol. 2003, 73, 315-322. [CrossRef] [PubMed]

67. Watson, R.W.; Rotstein, O.D.; Parodo, J.; Bitar, R.; Hackam, D.; Marshall, J.C. Granulocytic differentiation of HL-60 cells results in spontaneous apoptosis mediated by increased caspase expression. FEBS Lett. 1997, 412, 603-609. [CrossRef]

68. Maianski, N.A.; Geissler, J.; Srinivasula, S.M.; Alnemri, E.S.; Roos, D.; Kuijpers, T.W. Functional characterization of mitochondria in neutrophils: A role restricted to apoptosis. Cell. Death Differ. 2004, 11, 143-153. [CrossRef]

69. Gomes-Silva, D.; Atilla, E.; Atilla, P.A.; Mo, F.; Tashiro, H.; Srinivasan, M.; Lulla, P.; Rouce, R.H.; Cabral, J.M.S.; Ramos, C.A.; et al. CD7 CAR T Cells for the Therapy of Acute Myeloid Leukemia. Mol. Ther. 2019, 27, 272-280. [CrossRef]

70. Walter, R.B. Investigational CD33-targeted therapeutics for acute myeloid leukemia. Expert Opin. Investig. Drugs 2018, 27, 339-348. [CrossRef]

71. Naik, J.; Themeli, M.; de Jong-Korlaar, R.; Ruiter, R.W.J.; Poddighe, P.J.; Yuan, H.; de Bruijn, J.D.; Ossenkoppele, G.J.; Zweegman, S.; Smit, L.; et al. CD38 as a therapeutic target for adult acute myeloid leukemia and T-cell acute lymphoblastic leukemia. Haematologica 2019, 104, 100-103. [CrossRef] [PubMed]

72. van Galen, P.; Hovestadt, V.; Wadsworth Ii, M.H.; Hughes, T.K.; Griffin, G.K.; Battaglia, S.; Verga, J.A.; Stephansky, J.; Pastika, T.J.; Lombardi Story, J.; et al. Single-Cell RNA-Seq Reveals AML Hierarchies Relevant to Disease Progression and Immunity. Cell 2019, 176, 1265-1281. [CrossRef] [PubMed] 
73. van Gils, N.; Verhagen, H.; Smit, L. Reprogramming acute myeloid leukemia into sensitivity for retinoic-acid-driven differentiation. Exp. Hematol. 2017, 52, 12-23. [CrossRef] [PubMed]

74. Verhagen, H.; van Gils, N.; Martianez, T.; van Rhenen, A.; Rutten, A.; Denkers, F.; de Leeuw, D.C.; Smit, M.A.; Tsui, M.L.; de Vos Klootwijk, L.L.E.; et al. IGFBP7 Induces Differentiation and Loss of Survival of Human Acute Myeloid Leukemia Stem Cells without Affecting Normal Hematopoiesis. Cell. Rep. 2018, 25, 3021-3035. [CrossRef]

75. Sica, A.; Guarneri, V.; Gennari, A. Myelopoiesis, metabolism and therapy: A crucial crossroads in cancer progression. Cell. Stress 2019, 3, 284-294. [CrossRef]

76. Mathias, B.; Delmas, A.L.; Ozrazgat-Baslanti, T.; Vanzant, E.L.; Szpila, B.E.; Mohr, A.M.; Moore, F.A.; Brakenridge, S.C.; Brumback, B.A.; Moldawer, L.L.; et al. Human Myeloid-derived Suppressor Cells are Associated With Chronic Immune Suppression After Severe Sepsis/Septic Shock. Ann. Surg. 2017, 265, 827-834. [CrossRef]

77. Janols, H.; Bergenfelz, C.; Allaoui, R.; Larsson, A.M.; Ryden, L.; Bjornsson, S.; Janciauskiene, S.; Wullt, M.; Bredberg, A.; Leandersson, K. A high frequency of MDSCs in sepsis patients, with the granulocytic subtype dominating in gram-positive cases. J. Leukoc. Biol. 2014, 96, 685-693. [CrossRef]

78. McPeak, M.B.; Youssef, D.; Williams, D.A.; Pritchett, C.; Yao, Z.Q.; McCall, C.E.; El Gazzar, M. Myeloid Cell-Specific Knockout of NFI-A Improves Sepsis Survival. Infect. Immun. 2017, 85. [CrossRef]

79. Szebeni, G.J.; Kriston-Pal, E.; Blazso, P.; Katona, R.L.; Novak, J.; Szabo, E.; Czibula, A.; Fajka-Boja, R.; Hegyi, B.; Uher, F.; et al. Identification of galectin-1 as a critical factor in function of mouse mesenchymal stromal cell-mediated tumor promotion. PLoS ONE 2012, 7, e41372. [CrossRef]

80. Fajka-Boja, R.; Szebeni, G.J.; Hunyadi-Gulyas, E.; Puskas, L.G.; Katona, R.L. Polyploid Adipose Stem Cells Shift the Balance of IGF1/IGFBP2 to Promote the Growth of Breast Cancer. Front. Oncol. 2020, 10, 157. [CrossRef]

81. Szebeni, G.J.; Balazs, A.; Madarasz, I.; Pocz, G.; Ayaydin, F.; Kanizsai, I.; Fajka-Boja, R.; Alfoldi, R.; Hackler, L., Jr.; Puskas, L.G. Achiral Mannich-Base Curcumin Analogs Induce Unfolded Protein Response and Mitochondrial Membrane Depolarization in PANC-1 Cells. Int. J. Mol. Sci. 2017, 18. [CrossRef] [PubMed]

82. Kovacs, A.K.; Hegyes, P.; Szebeni, G.J.; Nagy, L.I.; Puskas, L.G.; Toth, G.K. Synthesis of N-peptide-6-amino-D-luciferin Conjugates. Front. Chem. 2018, 6, 120. [CrossRef] [PubMed]

83. Szebeni, G.J.; Tancos, Z.; Feher, L.Z.; Alfoldi, R.; Kobolak, J.; Dinnyes, A.; Puskas, L.G. Real architecture For 3D Tissue (RAFT) culture system improves viability and maintains insulin and glucagon production of mouse pancreatic islet cells. Cytotechnology 2017, 69, 359-369. [CrossRef] [PubMed]

84. Bertagnolo, V.; Grassilli, S.; D’Aguanno, S.; Brugnoli, F.; Bavelloni, A.; Faenza, I.; Nika, E.; Urbani, A.; Cocco, L.; Capitani, S. Mass spectrometry-based identification of Y745 of Vav1 as a tyrosine residue crucial in maturation of acute promyelocytic leukemia-derived cells. J. Proteome Res. 2010, 9, 752-760. [CrossRef]

85. Posa, A.; Szabo, R.; Csonka, A.; Veszelka, M.; Berko, A.M.; Barath, Z.; Menesi, R.; Pavo, I.; Gyongyosi, M.; Laszlo, F.; et al. Endogenous Estrogen-Mediated Heme Oxygenase Regulation in Experimental Menopause. Oxid. Med. Cell. Longev. 2015, 2015, 429713. [CrossRef]

86. Alfoldi, R.; Balog, J.A.; Farago, N.; Halmai, M.; Kotogany, E.; Neuperger, P.; Nagy, L.I.; Feher, L.Z.; Szebeni, G.J.; Puskas, L.G. Single Cell Mass Cytometry of Non-Small Cell Lung Cancer Cells Reveals Complexity of In vivo And Three-Dimensional Models over the Petri-dish. Cells 2019, 8. [CrossRef]

C 2020 by the authors. Licensee MDPI, Basel, Switzerland. This article is an open access article distributed under the terms and conditions of the Creative Commons Attribution (CC BY) license (http://creativecommons.org/licenses/by/4.0/). 